University of Nebraska - Lincoln DigitalCommons@University of Nebraska - Lincoln

2004

CONCENTRATIONS OF ARSENIC, CADMIUM, COPPER, LEAD, SELENIUM, AND ZINC IN FISH FROM THE MISSISSIPPI RIVER BASIN, 1995

Christopher J. Schmitt

U.S. Geological Survey, cjschmitt@usgs.gov

Follow this and additional works at: http:/ / digitalcommons.unl.edu/usgsstaffpub

Schmitt, Christopher J., "CONCENTRATIONS OF ARSENIC, CADMIUM, COPPER, LEAD, SELENIUM, AND ZINC IN FISH FROM THE MISSISSIPPI RIVER BASIN, 1995" (2004). USGS Staff -- Published Research. 884.

http://digitalcommons.unl.edu/usgsstaffpub/884

This Article is brought to you for free and open access by the US Geological Survey at DigitalCommons@University of Nebraska - Lincoln. It has been accepted for inclusion in USGS Staff -- Published Research by an authorized administrator of DigitalCommons@University of Nebraska - Lincoln. 


\title{
CONCENTRATIONS OF ARSENIC, CADMIUM, COPPER, LEAD, SELENIUM, AND ZINC IN FISH FROM THE MISSISSIPPI RIVER BASIN, 1995
}

\author{
CHRISTOPHER J. SCHMITT \\ U.S. Geological Survey, Columbia Environmental Research Center, Columbia, Missouri, U.S.A. \\ (* author for correspondence, e-mail: christopher_schmitt@usgs.gov)
}

(Received 5 March 2002; accepted 6 February 2003)

\begin{abstract}
Fish were collected in late 1995 from 34 National Contaminant Biomonitoring Program (NCBP) stations and 12 National Water Quality Assessment Program (NAWQA) stations in the Mississippi River basin (MRB), and in late 1996 from a reference site in West Virginia. The NCBP sites represented key points (dams, tributaries, etc.) in the largest rivers of the MRB. The NAWQA sites were typically on smaller rivers and were selected to represent dominant land uses in their watersheds. The West Virginia site, which is in an Eastern U.S. watershed adjacent to the MRB, was selected to document elemental concentrations in fish used for other aspects of a larger study and to provide additional contemporaneous data on background elemental concentrations. At each site four samples, each comprising (nominally) 10 adult common carp (Cyprinus carpio, 'carp') or black bass (Micropterus spp., 'bass') of the same sex, were collected. The whole fish were composited by station, species, and gender for analysis of arsenic (As), lead ( $\mathrm{Pb})$, and selenium $(\mathrm{Se})$ by atomic absorption spectroscopy and for cadmium $(\mathrm{Cd})$, copper $(\mathrm{Cu})$, and zinc $(\mathrm{Zn})$ by inductively-coupled plasma emission spectroscopy. Concentrations of most of the elements examined were lower in both carp and bass from the reference site, a small impoundment located in a rural area, than from the NCBP and NAWQA sites on rivers and larger impoundments. In contrast, there were few overall differences between NCBP sites NAWQA sites. The 1995 results generally confirmed the continued weathering and re-distribution of these elemental contaminants in the MRB; concentrations declined or were unchanged from 1984-1986 to 1995 at most NCBP sites, thus continuing two-decade trends. Exceptions were Se at Station 77 (Arkansas R. at John Martin Reservoir, CO), where concentrations have been elevated historically and increased slightly (to $3.8-4.7 \mu \mathrm{g} \mathrm{g}^{-1}$ in bass and carp); and $\mathrm{Pb}$, $\mathrm{Cd}$, and $\mathrm{Zn}$ at Station 67 (Allegheny R. at Natrona, PA), where levels of these metals were high in the past and increased from 1986 to 1995.
\end{abstract}

Keywords: Arkansas River, arsenic, cadmium, copper, irrigation, lead, metals, Mississippi River, Missouri River, monitoring, Ohio River, Red River, selenium, Tennessee River, zinc

\section{Introduction}

Environmental concentrations of many persistent environmental contaminants have generally declined over the last two decades (Schmitt and Bunck, 1995; Schmitt et al., 1999b; Gundersen et al., 2000), ostensibly as a result of environmental regu-

The U.S. Government's right to retain a non-exclusive, royalty free licence in and to any copyright is acknowledged. 
lation. Nevertheless, there is a substantial body of information indicating that concentrations of organochlorine chemicals, mercury $(\mathrm{Hg})$, and other persistent contaminants in fish may remain sufficiently elevated to harm fish and wildlife in some areas, and levels of some may be rising (e.g., Gooch and Matsamura, 1987; Colborn, 1991; Tillitt et al., 1992; Farag et al., 1994, 1995; Schmitt and Bunck, 1995; Woodward et al., 1997; Yeardley et al., 1998; Schmitt, 1999, 2002a, b; Schmitt et al., 1999b, 2002; Stansley and Roscoe, 1999; Wildhaber et al., 2000; Brumbaugh et al., 2001). Concentrations of persistent contaminants in fish are therefore measured as integral parts of many environmental monitoring programs (Hirsch et al., 1988; Messer et al., 1989; Biomonitoring of Environmental Status and Trends Program (BEST), 1996; Schmitt and Dethloff, 2000) and have been recommended as indicators of sustainable economic development (U.S. Council on Environmental Quality, 1997).

This paper summarizes one part of a larger investigation conducted in 19951996 that included both chemical and biological indicators (Schmitt, 2002a) and which was designed to assess the exposure of fish in rivers of the Mississippi River Basin (MRB) to environmental contaminants. The paper provides contemporary information on the distribution, concentrations, and ecological risks of arsenic (As), cadmium $(\mathrm{Cd})$, copper $(\mathrm{Cu})$, lead $(\mathrm{Pb})$, selenium $(\mathrm{Se})$, and zinc $(\mathrm{Zn})$ in fish from the MRB, where contaminants in fish had not been evaluated comprehensively since the mid-1980s (Schmitt and Bunck, 1995; Schmitt et al., 1999b). The results are compared with previous findings of the National Contaminant Biomonitoring Program (NCBP) and relevant contemporaneous studies, and are evaluated relative to extant information on ecological risk of elemental contaminants in fish. The fish samples collected and analyzed for this study were also analyzed for organochlorine chemical residues and for $\mathrm{Hg}$. Organochlorine findings have been published (Schmitt, 2000b), and those for $\mathrm{Hg}$ will be presented in another paper. Raw data for the entire study, as well as 1969-1986 NCBP data, may be obtained at <http://www.cerc.usgs.gov/data/data.htm>.

\section{Methods and Materials}

\subsubsection{Study area and collection sites}

The MRB drains all or parts of 32 states (about $41 \%$ of the conterminous U.S.) and parts of two Canadian provinces (Figure 1), and has a human population of more than 72 million. Agricultural development in the MRB is extensive, accounting for $>50 \%$ of U.S. corn, wheat, soybean, cattle, and hog production (Goolsby, 1996). There is also substantial urban, industrial, and mining activity. Consequently, many programs and studies (e.g., Trefry et al., 1985; Garbarino et al., 1995; Heiny and Tate, 1997; Schmitt et al., 1999b; Horowitz et al., 2001) have documented the presence and widespread distribution of elemental contaminants of agricultural, industrial, and mining origin in the Mississippi River and its tributaries as well as 


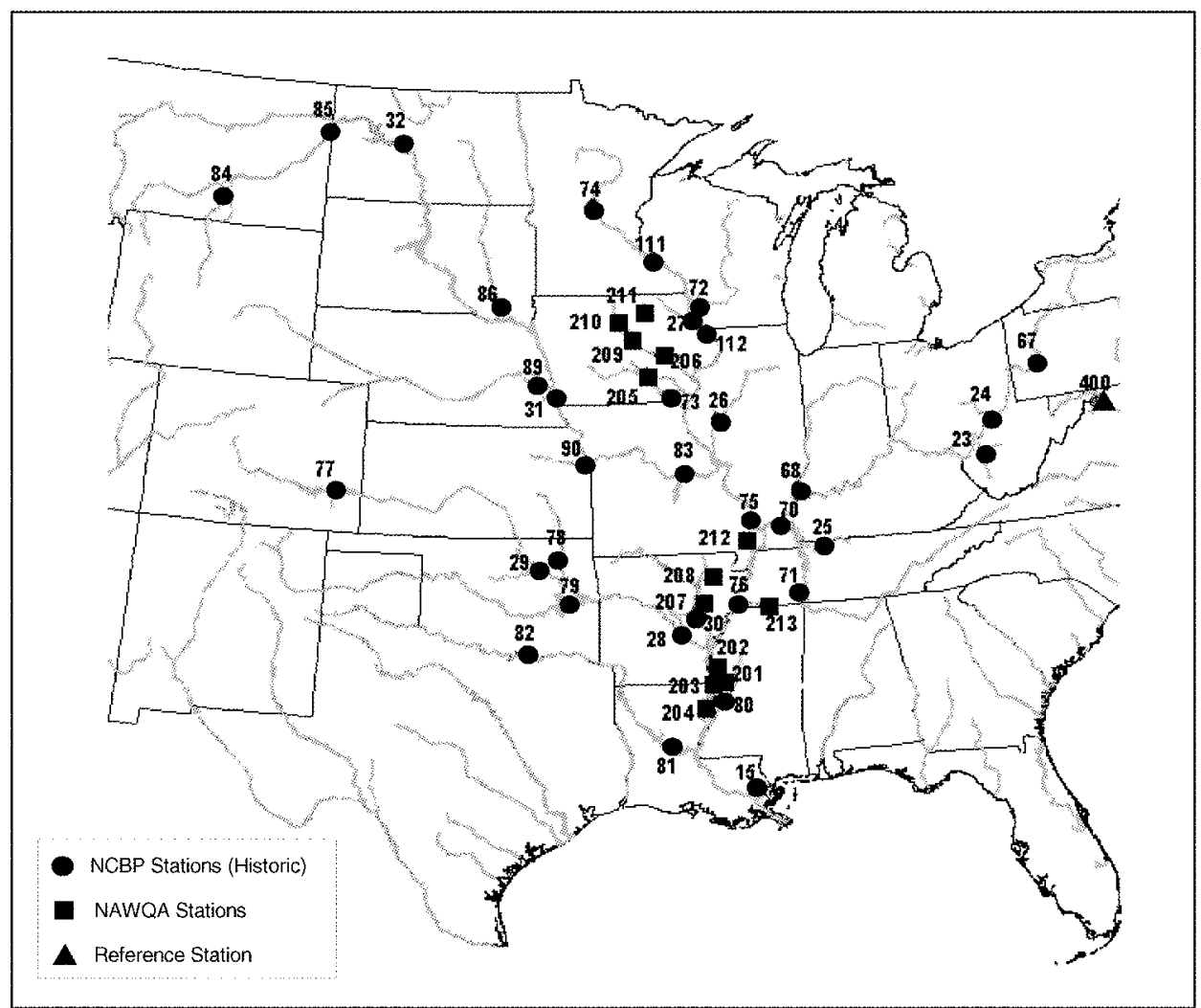

Figure 1. Map of the Mississippi River Basin showing the stations sampled in 1995 (1996 for Station 400). See Table I for station locations.

the export of nutrients and contaminants to the Gulf of Mexico (Trefry et al., 1985; Meade, 1995; Rostad, 1997). Information on contaminants in the large rivers of the MRB needed to be updated because substantial quantities of pesticides, nutrients, and other materials were re-distributed within and transported out of the basin by extreme flooding in 1993 and 1995 (Rostad, 1997).

Fish were collected in late 1995 from 34 NCBP stations in the MRB (Figure 1, Table I). At these sites, which represent key points (i.e., confluences of major tributaries, dams) on some of the largest U.S. rivers, concentrations of accumulative contaminants in fish were monitored from 1967 through 1986 (Schmitt and Bunck, 1995; Schmitt et al., 1999b). Fish were also collected in 1995 at 12 National Water Quality Assessment Program (NAWQA) sites - nine in the Mississippi Embayment (MSE) Study Unit (Mallory, 1994) and four in the Eastern Iowa Basins (EIB) Study Unit (Kalkhoff et al., 1994; Figure 1, Table I). The NAWQA sites are typically situated on lower-order rives and streams than the NCBP sites, and they were selected to represent prevalent land-use patterns in their respective basins. In late 1996, samples were collected from the water supply reservoirs of the USGS 
Leetown Science Center in Kearneysville, WV (Table I). This site is located in the upper Potomac River watershed, which is adjacent to the easternmost drainages of the MRB (Figure 1). The site was sampled primarily because it was the source of the fish used to develop some of the biological methods used in the larger study (Schmitt and Dethloff, 2000; Schmitt, 2002a); their contaminant content had not been previously determined. Because all the NCBP and NAWQA sites in the MRB are contaminated to some degree, the West Virginia site was also believed to provide additional information on contemporary background concentrations. Additional contemporaneous data for elemental contaminants in carp were available from two sources: a NAWQA investigation conducted in the Red River of the North (RRN) basin (Brigham et al., 1998; Goldstein et al., 1996; Goldstein and DeWeese, 1999); and a recent study of metals in fish from waters contaminated by $\mathrm{Pb}$ smelters that included the Mississippi River at Herculaneum, MO (Schmitt et al., 2002). The U.S. parts of the RRN basin lie completely within the NorthCentral MRB and, like adjacent parts of the MRB, much of the RRN watershed is devoted to agriculture and is sparsely populated; however, the population centers of the RRN basin support little industry and there is no mining (Brigham et al., 1998). In contrast, the Herculaneum smelter has operated since 1864 and the Mississippi River near the site is heavily contaminated (Schmitt et al., 2002). Herculaneum is $160 \mathrm{~km}$ upstream from NCBP Station 75 (Mississippi R. at Cape Girardeau, MO; Table I).

\subsection{TARGET SPECIES AND SAMPLING STRATEGY}

This study was designed to retain comparability with historic NCBP data (Schmitt et al., 1999b) and other investigations based on composite samples of whole fish while also accommodating the biological measurements incorporated into the larger study (Schmitt and Dethloff, 2000), many of which are gender-specific and require live or freshly killed individual fish. Common carp (Cyprinus carpio, hereafter 'carp') and black bass (Micropterus sp., 'bass') were targeted for collection. These taxa were selected because they are widely distributed and were prevalent in past NCBP and NAWQA collections in the MRB (Crawford and Luoma, 1993; Heiny and Tate, 1997; Schmitt et al., 1999b) and because the biological endpoints measured in other components of the larger study (Schmitt, 2002a) had been most thoroughly tested in them. The collection target at NCBP sites and the reference site was 10 (each) adult male and female of each taxon - 40 fish per site. Both carp and bass were sought at only one NAWQA site; carp were targeted exclusively at 10 , and only largemouth bass (M. salmoides) were sought at one. Collectors were instructed to obtain adult carp and bass of a size representative of those believed to be present based on extant information, and to avoid extremely large or small fish. Alternate species were permitted if carp or bass were not available. 


\section{TABLE I}

Locations of National Contaminant Biomonitoring Program (NCBP) and National Water Quality Assessment Program (NAWQA) stations in the Mississippi River basin sampled in 1995, and of the reference site sampled in 1996

\begin{tabular}{lll}
\hline $\begin{array}{l}\text { Program, sub-basin } \\
\text { (NCBP) or Study }\end{array}$ & River & $\begin{array}{l}\text { Nearest city } \\
\text { or feature }\end{array}$ \\
$\begin{array}{l}\text { Unit (NAWQA), } \\
\text { and station number }\end{array}$ & & Latitude, longitude \\
\hline
\end{tabular}

NCBP

Arkansas-Red R. (ARR)

$\begin{array}{llll}29 & \text { Arkansas } & \text { Keystone Res., OK } & 36^{\circ} 07^{\prime} 54.0^{\prime \prime} \mathrm{N}, 96^{\circ} 20^{\prime} 47.0^{\prime \prime} \mathrm{W} \\ 77 & \text { Arkansas } & \text { John Martin Res., OK } & 38^{\circ} 03^{\prime} 55.0^{\prime \prime} \mathrm{N}, 102^{\circ} 56^{\prime} 02.0^{\prime \prime} \mathrm{W} \\ 78 & \text { Verdigris } & \text { Oolagah, OK } & 36^{\circ} 31^{\prime} 16.0^{\prime \prime} \mathrm{N}, 95^{\circ} 33^{\prime} 37.0^{\prime \prime} \mathrm{W} \\ 79 & \text { Canadian } & \text { Eufaula, OK } & 35^{\circ} 16^{\prime} 43.0^{\prime \prime} \mathrm{N}, 95^{\circ} 34^{\prime} 39.0^{\prime \prime} \mathrm{W} \\ 82 & \text { Red } & \text { Lake Texoma, TX/OK } & 33^{\circ} 52^{\prime} 08.0^{\prime \prime} \mathrm{N}, 96^{\circ} 47^{\prime} 04.0^{\prime \prime} \mathrm{W}\end{array}$

Lower Missouri R. (LMO)

$\begin{array}{llll}31 & \text { Missouri } & \text { Nebraska City, NE } & 40^{\circ} 40^{\prime} 15.9^{\prime \prime} \mathrm{N}, 95^{\circ} 49^{\prime} 44.6^{\prime \prime} \mathrm{W} \\ 83 & \text { Missouri } & \text { Hermann, MO } & 38^{\circ} 42^{\prime} 24.1^{\prime \prime} \mathrm{N}, 91^{\circ} 26^{\prime} 17.5^{\prime \prime} \mathrm{W} \\ 86 & \text { James } & \text { Olivet, SD } & 43^{\circ} 13^{\prime} 45.0^{\prime \prime} \mathrm{N}, 97^{\circ} 41^{\prime} 05.0^{\prime \prime} \mathrm{W} \\ 89 & \text { Platte } & \text { Louisville, NE } & 40^{\circ} 59^{\prime} 33.1^{\prime \prime} \mathrm{N}, 96^{\circ} 12^{\prime} 30.9^{\prime \prime} \mathrm{W} \\ 90 & \text { Kansas } & \text { Bonner Springs, KS } & 39^{\circ} 02^{\prime} 47.0^{\prime \prime} \mathrm{N}, 94^{\circ} 47^{\prime} 05.0^{\prime \prime} \mathrm{W}\end{array}$

Upper Missouri R. (UMO)

$\begin{array}{llll}32 & \text { Missouri } & \text { Garrison Dam, ND } & 47^{\circ} 28^{\prime} 27.3^{\prime \prime} \mathrm{N}, 101^{\circ} 26^{\prime} 15.5^{\prime \prime} \mathrm{W} \\ 84 & \text { Big Horn } & \text { Hardin, MT } & 45^{\circ} 52^{\prime} 12.2^{\prime \prime} \mathrm{N}, 107^{\circ} 34^{\prime} 34.0^{\prime \prime} \mathrm{W} \\ 85 & \text { Yellowstone } & \text { Sidney, NE } & 47^{\circ} 34^{\prime} 46.8^{\prime \prime} \mathrm{N}, 104^{\circ} 13^{\prime} 10.7^{\prime \prime} \mathrm{W}\end{array}$

Lower Mississippi R. (LMS)

$\begin{array}{llll}15 & \text { Mississippi } & \text { Luling, LA } & 29^{\circ} 59^{\prime} 53.2^{\prime \prime} \mathrm{N}, 90^{\circ} 25^{\prime} 31.1^{\prime \prime} \mathrm{W} \\ 28 & \text { Arkansas } & \text { Pine Bluff, AR } & 34^{\circ} 16^{\prime} 27.0^{\prime \prime} \mathrm{N}, 94^{\circ} 57^{\prime} 12.0^{\prime \prime} \mathrm{W} \\ 30 & \text { White } & \text { Devall's Bluff, AR } & 34^{\circ} 47^{\prime} 01.0^{\prime \prime} \mathrm{N}, 91^{\circ} 26^{\prime} 28.0^{\prime \prime} \mathrm{W} \\ 75 & \text { Mississippi } & \text { Cape Girardeau, MO } & 37^{\circ} 18^{\prime} 36.0^{\prime \prime} \mathrm{N}, 89^{\circ} 31^{\prime} 01.2^{\prime \prime} \mathrm{W} \\ 76 & \text { Mississippi } & \text { Memphis, TN } & 38^{\circ} 08^{\prime} 30.3^{\prime \prime} \mathrm{N}, 90^{\circ} 03^{\prime} 36.6^{\prime \prime} \mathrm{W} \\ 80 & \text { Yazoo } & \text { Redwood, MS } & 32^{\circ} 24^{\prime} 36.0^{\prime \prime} \mathrm{N}, 90^{\circ} 55^{\prime} 27.0^{\prime \prime} \mathrm{W} \\ 81 & \text { Red } & \text { Alexandria, LA } & 31^{\circ} 20^{\prime} 48.0^{\prime \prime} \mathrm{N}, 92^{\circ} 27^{\prime} 37.0^{\prime \prime} \mathrm{W}\end{array}$

Upper Mississippi R. (UMS)

\begin{tabular}{llll}
26 & Illinois & Beardstown, IL & $40^{\circ} 07^{\prime} 50.6^{\prime \prime} \mathrm{N}, 90^{\circ} 20^{\prime} 45.6^{\prime \prime} \mathrm{W}$ \\
27 & Mississippi & Guttenburg, IA & $42^{\circ} 43^{\prime} 37.2^{\prime \prime} \mathrm{N}, 91^{\circ} 01^{\prime} 30.0^{\prime \prime} \mathrm{W}$ \\
72 & Wisconsin & Woodman, WI & $43^{\circ} 05^{\prime} 42.0^{\prime \prime} \mathrm{N}, 90^{\circ} 48^{\prime} 57.6^{\prime \prime} \mathrm{W}$ \\
\hline
\end{tabular}


TABLE I

(continued)

\begin{tabular}{llll}
\hline $\begin{array}{l}\text { Program, sub-basin } \\
\text { (NCBP) or Study }\end{array}$ & River & $\begin{array}{l}\text { Nearest city } \\
\text { or feature }\end{array}$ & Latitude, longitude \\
$\begin{array}{l}\text { Unit (NAWQA), } \\
\text { and station number }\end{array}$ & & \\
\hline
\end{tabular}

Upper Mississippi R. (UMS) (continued)

$\begin{array}{rlll}73 & \text { Des Moines } & \text { Keosauqua, IA } & 40^{\circ} 44^{\prime} 52.8^{\prime \prime} \mathrm{N}, 91^{\circ} 59^{\prime} 38.4^{\prime \prime} \mathrm{W} \\ 74 & \text { Mississippi } & \text { Little Falls, MN } & 45^{\circ} 58^{\prime} 48.0^{\prime \prime} \mathrm{N}, 94^{\circ} 22^{\prime} 00.0^{\prime \prime} \mathrm{W} \\ 111 & \text { Mississippi } & \text { Lake City, MN } & 44^{\circ} 22^{\prime} 49.8^{\prime \prime} \mathrm{N}, 92^{\circ} 07^{\prime} 33.0^{\prime \prime} \mathrm{W} \\ 112 & \text { Mississippi } & \text { Dubuque, IA } & 42^{\circ} 26^{\prime} 27.6^{\prime \prime} \mathrm{N}, 90^{\circ} 35^{\prime} 06.0^{\prime \prime} \mathrm{W}\end{array}$

Ohio R. (OHR)

$\begin{array}{llll}23 & \text { Kanawha } & \text { Winfield, WV } & 38^{\circ} 29^{\prime} 06.0^{\prime \prime} \mathrm{N}, 81^{\circ} 48^{\prime} 57.6^{\prime \prime} \mathrm{W} \\ 24 & \text { Ohio } & \text { Marietta, OH } & 39^{\circ} 24^{\prime} 36.8^{\prime \prime} \mathrm{N}, 81^{\circ} 26^{\prime} 26.3^{\prime \prime} \mathrm{W} \\ 25 & \text { Cumberland } & \text { Clarksville, OH } & 36^{\circ} 32^{\prime} 28.6^{\prime \prime} \mathrm{N}, 87^{\circ} 22^{\prime} 04.7^{\prime \prime} \mathrm{W} \\ 67 & \text { Allegheny } & \text { Natrona, PA } & 40^{\circ} 39^{\prime} 54.0^{\prime \prime} \mathrm{N}, 79^{\circ} 41^{\prime} 24.0^{\prime \prime} \mathrm{W} \\ 68 & \text { Wabash } & \text { New Harmony, IN } & 38^{\circ} 11^{\prime} 58.4^{\prime \prime} \mathrm{N}, 87^{\circ} 58^{\prime} 36.0^{\prime \prime} \mathrm{W} \\ 70 & \text { Ohio } & \text { Metropolis, IL } & 37^{\circ} 07^{\prime} 40.8^{\prime \prime} \mathrm{N}, 88^{\circ} 39^{\prime} 25.2^{\prime \prime} \mathrm{W} \\ 71 & \text { Tennessee } & \text { Savannah, TN } & 35^{\circ} 12^{\prime} 52.0^{\prime \prime} \mathrm{N}, 88^{\circ} 18^{\prime} 36.0^{\prime \prime} \mathrm{W}\end{array}$

\section{NAWQA}

Eastern Iowa Basins (EIB)

$\begin{array}{llll}205 & \text { S. Skunk } & \text { Oskaloosa, IA } & 41^{\circ} 21^{\prime} 19.0^{\prime \prime} \mathrm{N}, 92^{\circ} 39^{\prime} 31.0^{\prime \prime} \mathrm{W} \\ 206 & \text { Iowa } & \text { Morengo, IA } & 41^{\circ} 50^{\prime} 23.0^{\prime \prime} \mathrm{N}, 92^{\circ} 11^{\prime} 54.0^{\prime \prime} \mathrm{W} \\ 209^{\mathrm{a}} & \text { S. Fork Iowa } & \text { New Providence, IA } & 42^{\circ} 19^{\prime} 26.0^{\prime \prime} \mathrm{N}, 93^{\circ} 10^{\prime} 10.0^{\prime \prime} \mathrm{W} \\ 210 & \text { Iowa } & \text { Rowan, IA } & 42^{\circ} 45^{\prime} 36.0^{\prime \prime} \mathrm{N}, 93^{\circ} 37^{\prime} 23.0^{\prime \prime} \mathrm{W} \\ 211 & \text { Cedar } & \text { St. Charles City, IA } & 43^{\circ} 03^{\prime} 45.0^{\prime \prime} \mathrm{N}, 92^{\circ} 40^{\prime} 23.0^{\prime \prime} \mathrm{W}\end{array}$

Mississippi Embayment (MSE)

$\begin{array}{llll}201 & \text { Big Sunflower } & \text { Anguilla, MS } & 32^{\circ} 58^{\prime} 18.0^{\prime \prime} \mathrm{N}, 90^{\circ} 46^{\prime} 40.0^{\prime \prime} \mathrm{W} \\ 202 & \text { Bogue Phalia } & \text { Leland, MS } & 33^{\circ} 24^{\prime} 22.0^{\prime \prime} \mathrm{N}, 90^{\circ} 50^{\prime} 26.0^{\prime \prime} \mathrm{W} \\ 203 & \text { Steele Bayou } & \text { Rolling Fork, MS } & 32^{\circ} 54^{\prime} 71.0^{\prime \prime} \mathrm{N}, 90^{\circ} 57^{\prime} 10.0^{\prime \prime} \mathrm{W} \\ 204 & \text { Tensas } & \text { Tendal, LA } & 32^{\circ} 25^{\prime} 56.0^{\prime \prime} \mathrm{N}, 91^{\circ} 21^{\prime} 57.0^{\prime \prime} \mathrm{W} \\ 207 & \text { Cache } & \text { Cotton Plant, AR } & 35^{\circ} 02^{\prime} 32.0^{\prime \prime} \mathrm{N}, 91^{\circ} 19^{\prime} 12.0^{\prime \prime} \mathrm{W} \\ 208 & \text { Cache } & \text { Egypt, AR } & 35^{\circ} 51^{\prime} 23.0^{\prime \prime} \mathrm{N}, 90^{\circ} 56^{\prime} 15.0^{\prime \prime} \mathrm{W} \\ 212 & \text { Little R. Ditch } & \text { Moorehouse, MO } & 36^{\circ} 50^{\prime} 03.0^{\prime \prime} \mathrm{N}, 89^{\circ} 43^{\prime} 48.0^{\prime \prime} \mathrm{W} \\ 213 & \text { Wolf } & \text { LaGrange, TN } & 35^{\circ} 01^{\prime} 57.0^{\prime \prime} \mathrm{N}, 89^{\circ} 14^{\prime} 48.0^{\prime \prime} \mathrm{W}\end{array}$

Reference site (REF)

$400 \quad \begin{aligned} & \text { Leetown } \\ & \text { Reservoir }\end{aligned}$

${ }^{\text {a }}$ Samples from Station 209 were lost in transit. 


\subsection{FIELD PROCEDURES}

Fish were captured by electrofishing and held alive until they were processed (generally <4 hr) as described by Schmitt et al. (1999a). In short, each fish was measured, weighed, and placed on the dull side of a clean sheet of aluminum foil. The abdominal cavity was dissected open and gender was determined by gonadal observation. Samples of blood, liver, kidney, scales, and spleen were obtained for other analyses (Schmitt and Dethloff, 2000) after which all remaining tissues were returned to the carcass. The carcass was then wrapped in the foil on which it was processed, labeled, and chilled. Carcass samples comprised whole fish minus approximately $5 \mathrm{~mL}$ of blood, $5-81-\mathrm{cm}^{3}$ pieces of liver, five $1-\mathrm{cm}^{3}$ gonad pieces, the entire spleen, $5-10$ scales, and a $1-\mathrm{cm}^{3}$ piece of both the posterior and anterior kidneys. The total mass of tissues not included in the carcass analyses represented $<1 \%$ of the original mass of each fish. Between samples all contact surfaces and instruments were thoroughly cleaned with tap water and rinsed with de-ionized water and acetone. When all sampling at a station was completed, fish were frozen $\left(-20{ }^{\circ} \mathrm{C}\right)$ and shipped in dry ice to the analytical laboratory, where they were kept frozen until prepared for analysis. Scale samples from each fish were returned to the laboratory for age determination.

\subsection{LABORATORY ANALYSES}

Sample processing and elemental contaminant analyses were performed by contract laboratories under the supervision of the U.S. Fish and Wildlife Service (FWS)Patuxent Analytical Control Facility (PACF) in Laurel, MD, which maintained quality assurance $(\mathrm{Q} / \mathrm{A})$ oversight. For compatibility with other aspects of the larger study (Schmitt, 2002a) and previous studies in the MRB (e.g., Schmitt et al., 1999b), samples from each station were composited by species and gender. Individual fish were partly thawed and band-sawed into pieces. All the pieces of all the fish in the sample were then ground together three times with a commercial meat grinder. A $100 \mathrm{~g}$ sub-sample was retained and re-frozen for elemental contaminants and moisture analysis. Additional aliquots were prepared for Q/A and for analyses not reported here (Schmitt, 2002a, b). All equipment was disassembled, washed in hot soapy water, and rinsed with water, acetone, and petroleum ether between samples.

For analyses of elemental contaminants and moisture content, the 100-g aliquots of ground fish were freeze-dried and ground to 100-mesh with a cutter-hammer mill, which was rinsed thoroughly with $\mathrm{HNO}_{3}$ between samples. Moisture content was determined by weight loss during lyophilization. Freeze-dried fish $(0.25-0.50-$ g) was digested in $5 \mathrm{~mL}$ of $\mathrm{HNO}_{3}$ (Baker Instra-Analyzed) heated in a microwave oven (3 min@120 W, 3 min@300 W, 15 min @ 450 W), then diluted to $50 \mathrm{~mL}$ with ultrapure water. Concentrations of total $\mathrm{As}, \mathrm{Pb}$, and $\mathrm{Se}$ in the digestates were determined by graphite-furnace atomic absorption (AA) spectroscopy. Concentrations of total $\mathrm{Cd}, \mathrm{Cu}$, and $\mathrm{Zn}$, along with additional elements not reported here, 
TABLE II

Results of quality assurance analyses ${ }^{\mathrm{a}}$ for six elements

\begin{tabular}{lcccccc}
\hline Quality assurance component & \multicolumn{2}{l}{ Element } & & & & \\
\cline { 2 - 7 } & $\mathrm{As}$ & $\mathrm{Cd}$ & $\mathrm{Cu}$ & $\mathrm{Pb}$ & $\mathrm{Se}$ & $\mathrm{Zn}$ \\
\hline Duplicate sample analyses & & & & & & \\
Mean difference (\%) & 19.3 & 9.4 & 4.8 & 14.0 & 6.04 & 3.7 \\
SD & 23.4 & 4.8 & 3.6 & 10.5 & 3.8 & 2.9 \\
$\mathrm{n}$ & 3 & 5 & 9 & 8 & 9 & 9
\end{tabular}

Reference material, NRC DOLT-2 (Dogfish liver)

$\begin{array}{lcccccr}\begin{array}{l}\text { Certified concentration } \\ \left(\mu \mathrm{g} \mathrm{g}^{-1}, \mathrm{dw}\right)\end{array} & 16.60 & 20.80 & 25.80 & 0.22 & 6.06 & 85.8 \\ \text { 95\% CLM } & 1.10 & 0.50 & 1.10 & 0.02 & 0.49 & 2.5 \\ \text { Mean concentration } & 15.83 & 21.34 & 26.24 & 0.22 & 5.68 & 89.2 \\ \left(\mu \mathrm{g} \mathrm{g}^{-1}, \mathrm{dw}\right) & & & & & & \\ \text { SD } & 1.09 & 0.48 & 0.62 & 0.15 & 0.21 & 2.9 \\ \text { Mean recovery (\%) } & 95.3 & 102.5 & 101.7 & 98.7 & 93.7 & 103.9 \\ \text { SD }(\%) & 6.5 & 2.3 & 2.4 & 67.3 & 3.48 & 3.4 \\ n & 9 & 9 & 9 & 9 & 9 & 9\end{array}$

Fortified samples

\begin{tabular}{lcccccc} 
Mean recovery (\%) & 97.7 & 107.1 & 104.8 & 103.7 & 98.4 & 105.5 \\
SD & 11.0 & 3.8 & 2.6 & 1.9 & 3.0 & 14.6 \\
$n$ & 9 & 9 & 9 & 9 & 9 & 9 \\
\hline
\end{tabular}

a All blanks < LOD.

${ }^{b}$ Pairs (of 9) in which both analyses were > LOD.

were determined by inductively coupled plasma emission spectroscopy (ICPES) without pre-concentration using a Leeman ES200 simultaneous spectrometer. Q/A measures included analyses of blanks, fortified samples, duplicates, and standard reference materials (Table II). LODs were computed individually for each analyte in each sample, but were nominally $0.15 \mu \mathrm{g} \mathrm{g}^{-1}$ dry-weight (dw) for $\mathrm{Cd} ; 0.7 \mu \mathrm{g}$ $\mathrm{g}^{-1}$ for $\mathrm{As}, \mathrm{Cu}$, and $\mathrm{Se}, 2.5 \mu \mathrm{g} \mathrm{g}^{-1}$ for $\mathrm{Zn}$; and $3 \mu \mathrm{g} \mathrm{g}^{-1}$ for $\mathrm{Pb}$ (Table III). These values, as well as the analytical results, were converted to wet-weight (ww) concentrations (Table III) for statistical analysis and reporting and for comparisons with other studies.

Scale samples from each fish were cleaned, dried, and either mounted between glass microscope slides or pressed in acetate. They were read with the aid of either a 
TABLE III

Occurrence (percentages of samples and stations, including the reference site), limits of detection (LOD), and maximum concentrations of analytes in composite carcass samples

\begin{tabular}{|c|c|c|c|c|c|c|c|}
\hline \multirow[t]{2}{*}{ Analyte } & \multirow{2}{*}{$\begin{array}{l}\text { Samples } \\
\text { (\% of } 163 \text { ) }\end{array}$} & \multirow{2}{*}{$\begin{array}{l}\text { Stations } \\
(\% \text { of } 47)\end{array}$} & \multirow{2}{*}{$\begin{array}{l}\text { LOD range } \\
\left(\mu \mathrm{g} \mathrm{g}^{-1}\right)^{\mathrm{a}}\end{array}$} & \multicolumn{4}{|c|}{ Maximum 1995 concentrations } \\
\hline & & & & Conc. $\left(\mu \mathrm{g} \mathrm{g}^{-1}\right)$ & Station & Sex & Species \\
\hline Arsenic & 28 & 48 & $0.11-0.51$ & 0.56 & 78 & M & Largemouth bass \\
\hline Cadmium & 49 & 91 & $0.02-0.10$ & 0.51 & 67 & $\mathrm{M}$ & Carp \\
\hline Copper & 100 & 100 & $0.11-0.51$ & 3.8 & 15 & $\mathrm{~F}$ & White bass \\
\hline Lead & 87 & 100 & $0.01-0.04$ & 0.69 & 111 & M & Carp \\
\hline Selenium & 100 & 99 & $0.11-0.51$ & 4.7 & 77 & M & Carp \\
\hline Zinc & 100 & 100 & $0.23-1.66$ & 150 & 79 & M & Carp \\
\hline
\end{tabular}

${ }^{a}$ Wet-weight concentrations estimated from dry-weight values and moisture content.

dissecting microscope or scale projector, and age was estimated (yr) as the number of completed annuli (Jearld, 1993).

\subsection{DATA SET COMPOSITION AND STATISTICAL ANALYSES}

\subsubsection{Species Composition}

A total of 163 composite samples from 47 stations (including the reference site), which together represented 1308 fish, were analyzed; samples from one NAWQA site were lost in transit. Of the samples analyzed, 89 (55\%) from 45 stations (96\%) were carp and 58 samples (36\%) from 30 stations (64\%) were bass - largemouth, smallmouth (Micropterus dolomieui), and spotted (M. punctulatus). Most of these were largemouth bass, which were obtained from 23 stations. Exclusively smallmouth bass were obtained at four stations $(67,72,74$, and 111), and only spotted bass were collected at Station 23. Two samples each of both largemouth and spotted bass from one station (25) were analyzed, and the bass samples from one station (83) comprised both largemouth and spotted bass. The remaining 16 samples (10\%) comprised white sucker (Catostomus commersoni; two samples from one station), white bass (Morone chrysops; four samples, two stations), sauger (Stizostedion canadense; three samples, two stations), brown trout (Salmo trutta; two samples, one station), goldeye (Hiodon alosoides; two samples, one station), smallmouth buffalo (Ictiobus bubalus; two samples, one station), and northern pike (Esox lucius, one sample, one station). At most NCBP stations there was at least one species common to both the 1995 and 1986 collections (Schmitt et al., 1999b) for the examination of within-taxon temporal trends. For Station 90 (Kansas R.), where fish were not collected in 1986, 1995 data were compared to results from 1984 (Schmitt and Brumbaugh, 1990). 


\subsubsection{Fish Size and Age}

Concentrations of certain contaminants in fish increase with fish size, and these relationships as well as the concentrations vary among taxa (Goldstein et al., 1996; Goldstein and DeWeese, 1999; Schmitt et al., 1999b; Brumbaugh et al., 2002; Wiener et al., 2002). Accordingly, length, weight and age data of bass and carp were examined for extremes in variation and overall consistency across stations (Schmitt, 2002a). Most largemouth bass were 200-500 mm long, weighed 200 $1500 \mathrm{~g}$, and were 2-6 yr old. As is typical for these species, smallmouth and spotted bass were smaller than largemouth bass from some sites; however, most were similar in size to largemouth bass. The spotted and largemouth bass from Station 25 were nearly identical in size and age. Carp were more variable in length and weight than bass; most were 300-750 mm long, weighed 500-5000 g, and were 2-6 yr old. However, four carp were $>1000 \mathrm{~mm}, 10$ weighed $300-500 \mathrm{~g}$, and eight were 50007500 g. Carp and bass from the reference site were slightly smaller and younger than those from most MRB stations but similar in size to fish from several of the closest NCBP stations sampled (Stations 23 and 67). Overall, the sizes of the bass and carp analyzed were relatively consistent considering the wide geographic range and diversity of water body sizes and ecological conditions represented by the stations sampled. The size range of the bass comprised by the composite samples was smaller than those in the composite samples analyzed by Brumbaugh et al., (2002), and all bass in the composites were larger than the $180 \mathrm{~mm}$ total length mininum specified by Yeardley et al. (1998). A detailed analysis of the fish size and age information is presented elsewhere (Schmitt, 2002b).

\subsubsection{Statistical Analyses}

A value of one-half the LOD was substituted for censored values (i.e., $<$ LOD) in all computations, a procedure that introduces relatively little bias (U.S. Environmental Protection Agency (U.S. EPA), 2000). Preliminary analyses using Levene's test indicated that $\log _{10}$-transformed elemental concentrations reasonably approximated normality. Further analyses (ANOVA) indicated that for the elements reported here, differences between male and female carp and bass were not statistically significant $(p>0.05)$, and the samples representing male and female carp and bass from each station were treated as replicates in subsequent analyses. Withintaxon temporal and geographic comparisons were made where possible because elemental contaminant concentrations vary widely among fish taxa (Lowe et al., 1985; Schmitt et al., 1999b). For statistical testing of geographic trends, stations were aggregated by sub-basin and program (NCBP vs. NAWQA - Table I) for geographic analysis. The MSE and EIB Study Units are wholly contained within the Lower Mississippi River (LMS) and Upper Mississippi River (UMS) subbasins, respectively (Figure 1, Table I). Therefore, comparisons of these sub-basins represent regional contrasts of the large-river stations against those on lower-order rivers and streams, the latter selected based upon prevailing land-use patterns in their watersheds (Hirsch et al., 1988). Log-transformed concentrations of $\mathrm{Cd}, \mathrm{Cu}$, 
$\mathrm{Pb}, \mathrm{Se}$, and $\mathrm{Zn}$ in carp and bass and of $\mathrm{Cd}$ in carp were tested with a one-way ANOVA in which 'station' was treated as a fixed effect. Differences among sub-basins and programs were tested as planned contrasts using single degree-of-freedom $F$ tests. These analyses were not performed for As in either taxon or for $\mathrm{Cd}$ in bass because large percentages of the concentrations were censored; geographic and temporal comparisons for these elements were restricted to visual analyses. Temporal changes in concentrations of $\mathrm{Pb}, \mathrm{Se}, \mathrm{Zn}$, and $\mathrm{Cu}$ at individual NCBP stations were also tested by analyzing the log-transformed elemental concentrations in the 141 station-year-species combinations (total $N=242$ ) in the combined-year data set as a one-way ANOVA. Fisher's protected LSD was then used to contrast the 36 pairs of station-year-species means for each element that represented 1995 vs. 1986 concentrations (1984 for Station 90) in the same species at a site. A significance level of $\alpha=0.05$ was used in all statistical tests unless otherwise indicated.

\section{Results and Discussion}

\subsection{LEAD}

Environmental releases of $\mathrm{Pb}$ in North America have been greatly reduced over the last two decades through controls on industrial discharges and the elimination of $\mathrm{Pb}$ from motor fuels. Nevertheless, substantial quantities are still emitted by mining, smelting, and other activities and there is atmospheric transport from other parts of the world. In addition, much $\mathrm{Pb}$ remains in the environment from past emissions and uses (e.g., Schmitt et al., 2002). Not surprisingly, Pb was detected $\left(>0.006->0.032 \mu \mathrm{g} \mathrm{g}^{-1}\right)$ in $87 \%$ of the samples and in at least one sample from all stations sampled (Table II). At the West Virginia reference site, $\mathrm{Pb}$ was detected at low concentrations $\left(0.09-0.12 \mu \mathrm{g} \mathrm{g}^{-1}\right)$ in both carp samples but not in either sample of largemouth bass $\left(<0.03 \mu \mathrm{g} \mathrm{g}^{-1}\right.$; Figure 2). Concentrations were slightly greater in largemouth bass $\left(0.03-0.07 \mu \mathrm{g} \mathrm{g}^{-1}\right)$ than in spotted bass $\left(0.03 \mu \mathrm{g} \mathrm{g}^{-1}\right)$ from Station 25 (Cumberland R.), the only station from which both species were analyzed. The greatest $\mathrm{Pb}$ concentration $\left(0.69 \mu \mathrm{g} \mathrm{g}^{-1}\right)$ was in carp from Station 111 (Mississippi R. at Lake City, MN; Table III); concentrations in the other samples from this site were low $\left(<0.04-0.10 \mu \mathrm{g} \mathrm{g}^{-1}\right)$, however (Figure 2). $\mathrm{Pb}$ concentrations were also relatively high $\left(>0.2 \mu \mathrm{g} \mathrm{g}^{-1}\right.$ in one or both samples) in carp from NCBP Stations 67 (Allegheny R.), 85 (James R.), 24 (Ohio R.), 25 (Tennnesee R.), 28 (Arkansas R.), 78 (Verdigris R.), 79 (Canadian R.), 73 (Des Moines R.), and at NAWQA Station 204 (Tensas R.); in smallmouth buffalo from Station 23 (Kanawha R.); and in largemouth bass from Stations 28 and 70 (Ohio $\mathrm{R}$. at Metropolis, IL; Figure 2). Concentrations of $\mathrm{Pb}$ in carp from most sites in the MRB (Figure 2), including those in rural areas, were greater than the mean for whole carp from the RRN reported by Goldstein and DeWeese (1999), which was $0.14 \mu \mathrm{g} \mathrm{g}^{-1} \mathrm{dw}$ (about $0.04 \mu \mathrm{g} \mathrm{g}^{-1}$ ww using the $70 \%$ moisture content for 
RRN carp reported by Brigham et al. (1998)). The RRN values were similar to concentrations in carp from the West Virginia reference site, however (Figure 2). All $1995 \mathrm{~Pb}$ concentrations from the MRB, as well as those from the RRN and the reference site, were low compared to the 1.2-4.4 $\mu \mathrm{g} \mathrm{g}^{-1}$ reported for similar-sized carp and other fishes collected in 1992 from the Mississippi River at Herculaneum, MO by Schmitt et al. (2002).

Concentrations of $\mathrm{Pb}$ in MRB carp (2\% censored; i.e., < LOD) differed significantly among stations and sub-basins, but not programs, and no group of stations differed significantly from the reference site (Table IV). Among sub-basins, greatest concentrations were in the Ohio River (OHR) sub-basin and lowest were in the Lower Missouri River (LMO) and Lower Mississippi River (LMS) sub-basins and in the MSE Study Unit. The LMS and MSE did not differ significantly, nor did the EIB Study Unit differ from the Upper Mississippi River (UMS) sub-basin (Table IV). In bass (24\% censored), Pb concentrations also differed significantly among stations and sub-basin, with greatest levels occurring in the OHR and LMO sub-basins and lowest in the Arkansas-Red River (ARR) sub-basin and MSE Study Unit; the latter differed significantly (Table IV). Several sub-basins also differed significantly (greater) from the reference site (Table IV). Overall, concentrations of $\mathrm{Pb}$ in bass from the NCBP stations were significantly greater than levels at the NAWQA sites $(n=2)$, but neither group differed significantly from the reference site (Table IV).

Greatest $\mathrm{Pb}$ concentrations (individual samples, station means, or both) in 1986 (Schmitt et al., 1999b) occurred at several sites in the MRB where levels remained comparatively high in 1995: Stations 78 (Verdigris R.), 79 (Canadian R.), 89 (Platte R.), and 73 (Des Moines R.). In 1986, concentrations were also elevated at Station 69 (Ohio R. at Cincinnati, OH), which was not sampled in 1995, and at Stations 76 (Mississippi R. at Memphis, TN) and 83 (Missouri R. at Hermann, MO; Schmitt et al., 1999b). Relative to 1986 (1984 for Station 90), Pb concentrations decreased significantly at many of these NCBP stations where levels were historically elevated, especially in carp (Table V). In contrast, mean concentrations in carp about doubled from $0.24 \mathrm{~g} \mathrm{~g}^{-1}$ in 1986 to $0.45 \mathrm{~g} \mathrm{~g}^{-1}$ in 1995 at Station 67, where the 1995 $\mathrm{Pb}$ maximum occurred (Table III), but this change was not statistically significant (Table V). Although concentrations of $\mathrm{Pb}$ were generally lower in bass than in carp (Figure 2, Table V), concentrations in bass nevertheless increased significantly at Stations 67, 30 (White R.), 27 (Mississippi R. at Guttenburg, IA), and 72 (Wisconsin R.; Table V).

Although $\mathrm{Pb}$ is readily incorporated by fish into bones, scales, and certain organs (e.g., Farag et al., 1994), it does not biomagnify (Settle and Patterson, 1980). Consequently, there appears to be little risk to piscivorous wildlife from $\mathrm{Pb}$ in fish (Henny et al., 1994). Effects on heme synthesis in fish have been detected at carcass concentrations exceeding about $1.0 \mu \mathrm{g} \mathrm{g}^{-1}$, depending also on $\mathrm{Zn}$ burden (Schmitt et al., 1984, 1993). In laboratory studies other effects have been associated with higher whole-body concentrations (Jarvinen and Ankley, 1999). 


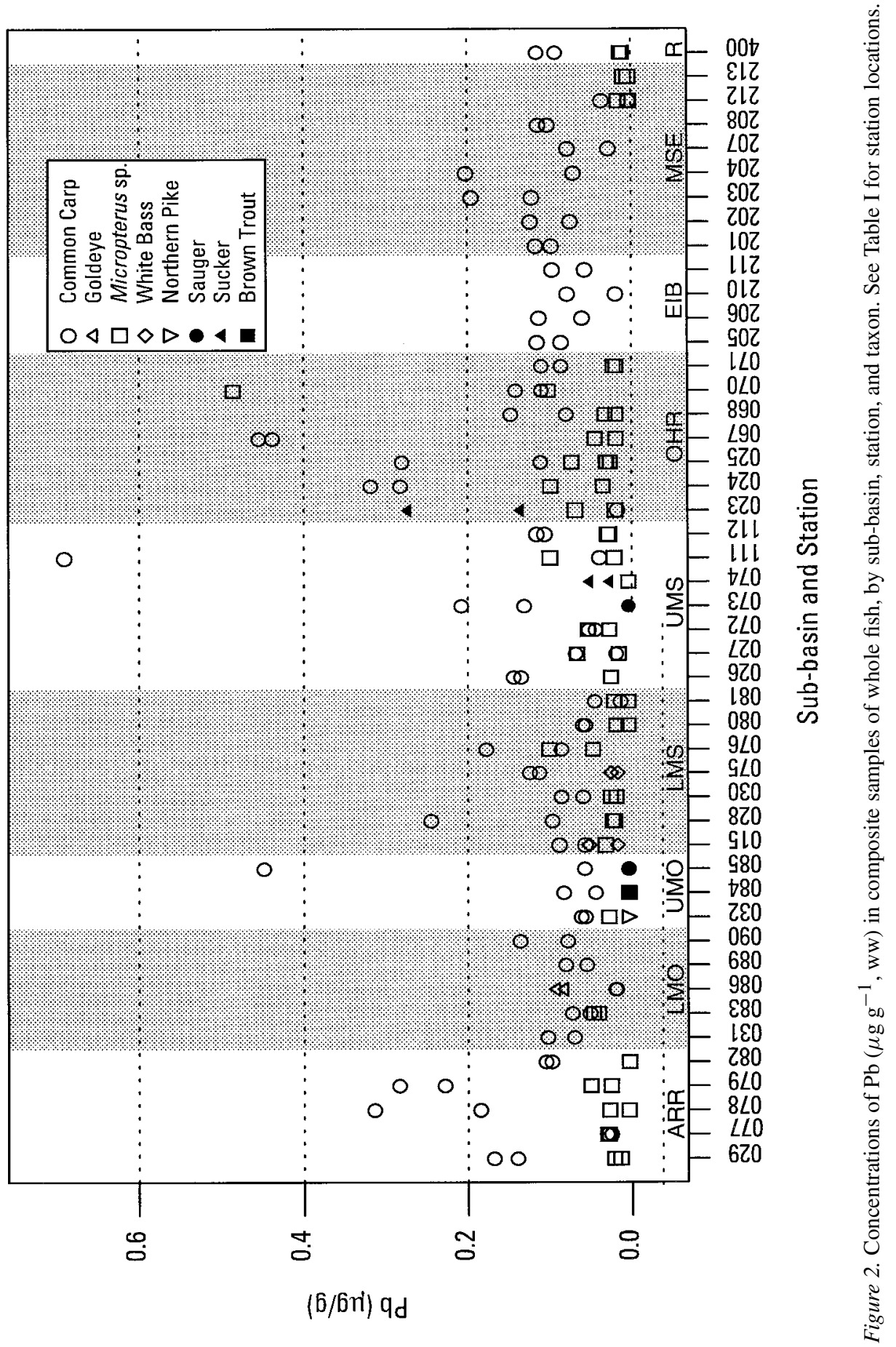


TABLE IV

Least-squares geometric mean concentrations of $\mathrm{Pb}, \mathrm{Se}, \mathrm{Cu}, \mathrm{Zn}$, and $\mathrm{Cd}$ in bass and carp $(\mathrm{Cd}$ in carp only, see text for explanation) collected from the MRB in 1995. Shown are means for sub-basins, programs, and the reference site, as identified in Table I. Also shown are ANOVA results as $F$-values ( ${ }^{* *} p<0.01$; ns, $p>0.05$ ) for among-station differences. Within columns (elements), sub-basin, program, and reference site means containing the same subscript do not differ significantly $(p>0.05)^{\mathrm{a}}$

\begin{tabular}{|c|c|c|c|c|c|c|}
\hline \multirow{2}{*}{$\begin{array}{l}\text { Taxon and sub-basin } \\
\text { (no. stations) }\end{array}$} & \multirow[t]{2}{*}{ Program } & \multicolumn{5}{|l|}{ Element } \\
\hline & & $\mathrm{Pb}$ & $\mathrm{Se}$ & $\mathrm{Cu}$ & $\mathrm{Zn}$ & $\mathrm{Cd}$ \\
\hline \multicolumn{7}{|l|}{ Bass } \\
\hline ARR (5) & NCBP & $0.01_{\mathrm{abc}}$ & $0.75_{\mathrm{ab}}$ & $0.49_{b}$ & $17.75_{\mathrm{a}}$ & - \\
\hline LMO (1) & $\mathrm{NCBP}$ & $0.04 \mathrm{a}$ & $0.59_{\mathrm{b}}$ & $0.56_{\mathrm{ab}}$ & $19.29 \mathrm{a}$ & - \\
\hline LMS (6) & $\mathrm{NCBP}$ & $0.02_{\mathrm{ab}}$ & $0.36_{\mathrm{a}}$ & $0.52_{\mathrm{cd}}$ & $18.05_{\mathrm{a}}$ & - \\
\hline MSE (2) & NAWQA & $0.01_{\mathrm{c}}$ & $0.39 \mathrm{c}$ & $0.57_{\mathrm{ab}}$ & $20.57 \mathrm{a}$ & - \\
\hline OHR (7) & NCBP & $0.04_{a}$ & $0.40_{\mathrm{c}}$ & $0.51_{\mathrm{b}}$ & $21.56_{\mathrm{a}}$ & - \\
\hline UMO (1) & NCBP & $0.03_{\mathrm{ab}}$ & $0.98 \mathrm{a}$ & $0.72_{\mathrm{a}}$ & $21.22 \mathrm{a}$ & - \\
\hline UMS (6) & NCBP & $0.02_{\mathrm{ab}}$ & $0.40_{\mathrm{c}}$ & $0.50_{\mathrm{b}}$ & $18.70_{\mathrm{a}}$ & - \\
\hline REF (1) & REF & $0.01_{\mathrm{ABbc}}$ & $0.28_{\mathrm{Aa}}$ & $0.48_{\text {Ad }}$ & $17.44_{\mathrm{Aa}}$ & - \\
\hline NCBP mean (28) & $\mathrm{NCBP}$ & $0.03_{\mathrm{B}}$ & $0.54_{\mathrm{B}}$ & $0.54_{\mathrm{A}}$ & $19.37_{\mathrm{A}}$ & - \\
\hline NAWQA mean (2) & NAWQA & $0.01_{\mathrm{A}}$ & $0.39_{\mathrm{C}}$ & $0.57_{\mathrm{A}}$ & $20.57_{\mathrm{A}}$ & - \\
\hline $\begin{array}{l}\text { ANOVA } F \\
(\mathrm{df}=28,29)\end{array}$ & - & $3.52^{* *}$ & $21.49^{* *}$ & $0.68 \mathrm{~ns}$ & $1.42 \mathrm{~ns}$ & - \\
\hline \multicolumn{7}{|l|}{ Carp } \\
\hline ARR (5) & NCBP & $0.12_{\mathrm{ab}}$ & $0.98_{\mathrm{a}}$ & $1.04_{\mathrm{a}}$ & $80.84_{a b c}$ & $0.09_{\mathrm{ab}}$ \\
\hline LMO (5) & NCBP & $0.06_{c}$ & $0.70_{\mathrm{bc}}$ & $1.15_{\mathrm{a}}$ & $62.50_{\mathrm{d}}$ & $0.07_{\mathrm{bc}}$ \\
\hline LMS (7) & NCBP & $0.08_{\mathrm{bc}}$ & $0.55_{\mathrm{cd}}$ & $1.05_{\mathrm{a}}$ & $63.32_{\mathrm{d}}$ & $0.05_{\mathrm{cd}}$ \\
\hline $\operatorname{MSE}(7)$ & NAWQA & $0.07_{\mathrm{bc}}$ & $0.76_{b}$ & $1.14 \mathrm{a}$ & $74.87_{\mathrm{bcd}}$ & $0.06_{\mathrm{bc}}$ \\
\hline OHR (7) & NCBP & $0.13 \mathrm{a}$ & $0.51_{\mathrm{d}}$ & $1.05 \mathrm{a}$ & $60.79_{\mathrm{cd}}$ & $0.11_{\mathrm{a}}$ \\
\hline UMO (3) & NCBP & $0.08_{\mathrm{abc}}$ & $0.82_{\mathrm{ab}}$ & $1.12_{\mathrm{a}}$ & $86.72_{\mathrm{ab}}$ & $0.07_{\mathrm{bc}}$ \\
\hline UMS (6) & NCBP & $0.10_{\mathrm{abc}}$ & $0.57_{\mathrm{cd}}$ & $1.07 \mathrm{a}$ & $93.07 \mathrm{a}$ & $0.05_{\mathrm{cd}}$ \\
\hline EIB (4) & NAWQA & $0.07_{\mathrm{bc}}$ & $0.67_{\mathrm{bcd}}$ & $1.02_{\mathrm{a}}$ & $74.94 \mathrm{bcd}$ & $0.04_{d}$ \\
\hline REF (1) & REF & $0.10_{\mathrm{Aabc}}$ & $0.13_{\mathrm{Ae}}$ & $0.98_{\mathrm{Aa}}$ & $40.64_{\mathrm{Ae}}$ & $0.01_{\mathrm{Ae}}$ \\
\hline NCBP mean (33) & $\mathrm{NCBP}$ & $0.09_{\mathrm{A}}$ & $0.67_{\mathrm{B}}$ & $1.08_{\mathrm{A}}$ & $73.44_{\mathrm{AB}}$ & $0.07_{\mathrm{B}}$ \\
\hline NAWQA mean (11) & $\mathrm{NCBP}$ & $0.07_{\mathrm{A}}$ & $0.71_{\mathrm{B}}$ & $1.08_{\mathrm{A}}$ & $74.91_{\mathrm{B}}$ & $0.05_{\mathrm{B}}$ \\
\hline $\begin{array}{l}\text { ANOVA } F \\
(\mathrm{df}=44,44)\end{array}$ & - & $3.00^{* *}$ & $8.02^{* *}$ & $1.38 \mathrm{~ns}$ & $4.01^{*}$ & $8.92^{* *}$ \\
\hline
\end{tabular}

a As determined by non-orthogonal, single degree-of-freedom (df) $F$-tests. 


\section{TABLE V}

Geometric mean concentrations ( $\mu \mathrm{g} \mathrm{g}^{-1}$, wet weight) of $\mathrm{Pb}, \mathrm{Se}, \mathrm{Zn}$, and $\mathrm{Cu}$ in 1986 (1984 for Station 90) for taxa common to both collections at the indicated stations (as identified in Table I). For each element, pairs of means containing the same subscript do not differ significantly $(p>0.05$, Fischer's protected LSD). Also shown are overall ANOVA $F$-values

\begin{tabular}{|c|c|c|c|c|c|c|c|c|c|}
\hline \multirow{3}{*}{$\begin{array}{l}\text { Sub-basin } \\
\text { and station }\end{array}$} & \multirow[t]{3}{*}{ Taxon } & \multicolumn{8}{|c|}{ Element and collection year } \\
\hline & & \multicolumn{2}{|l|}{$\mathrm{Pb}$} & \multicolumn{2}{|l|}{$\mathrm{Se}$} & \multicolumn{2}{|l|}{$\mathrm{Zn}$} & \multicolumn{2}{|l|}{$\mathrm{Cu}$} \\
\hline & & 1986 & 1995 & 1986 & 1995 & 1986 & 1995 & 1986 & 1995 \\
\hline \multicolumn{10}{|l|}{ ARR } \\
\hline 29 & Common carp & $0.20_{\mathrm{a}}$ & $0.15_{\mathrm{a}}$ & $0.43_{\mathrm{a}}$ & $0.50_{\mathrm{a}}$ & $55.2_{\mathrm{a}}$ & $67.8 \mathrm{a}$ & $0.72_{\mathrm{a}}$ & $0.93 \mathrm{a}$ \\
\hline 77 & Common carp & $0.05_{\mathrm{a}}$ & $0.03_{\mathrm{a}}$ & $3.34 \mathrm{a}$ & $4.19 \mathrm{a}$ & $71.9 \mathrm{a}$ & $83.9 \mathrm{a}$ & $0.72_{\mathrm{a}}$ & $0.98_{\mathrm{a}}$ \\
\hline 78 & Common carp & $0.53 \mathrm{a}$ & $0.24_{a}$ & $0.52_{\mathrm{a}}$ & $1.30_{\mathrm{b}}$ & $63.4_{a}$ & $85.6 \mathrm{a}$ & $1.00_{\mathrm{a}}$ & $1.14 \mathrm{a}$ \\
\hline 79 & Common carp & $0.43_{\mathrm{a}}$ & $0.25 \mathrm{a}$ & $0.39 \mathrm{a}$ & $0.53_{\mathrm{b}}$ & $53.4_{a}$ & $106.8_{\mathrm{b}}$ & $0.58 \mathrm{a}$ & $1.22 \mathrm{~b}$ \\
\hline 82 & Common carp & $0.14_{a}$ & $0.10_{\mathrm{a}}$ & $0.52_{\mathrm{a}}$ & $0.61_{\mathrm{a}}$ & $59.6_{\mathrm{a}}$ & $66.4_{a}$ & $0.88 \mathrm{a}$ & $0.98 \mathrm{a}$ \\
\hline
\end{tabular}

LMO

$\begin{array}{llllllllll}31 & \text { Common carp } & 0.10_{\mathrm{a}} & 0.09 \mathrm{a} & 1.01_{\mathrm{a}} & 0.77_{\mathrm{a}} & 62.8_{\mathrm{a}} & 66.7 \mathrm{a} & 0.87 \mathrm{a} & 1.15_{\mathrm{a}}\end{array}$

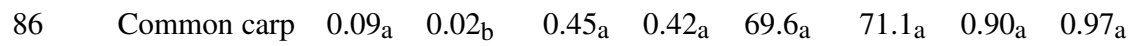

$\begin{array}{llllllllll}\text { Mooneye } & 0.24_{\mathrm{a}} & 0.09 \mathrm{a} & 0.88_{\mathrm{a}} & 0.91_{\mathrm{a}} & 20.6_{\mathrm{a}} & 30.8_{\mathrm{b}} & 0.63_{\mathrm{a}} & 0.45_{\mathrm{a}}\end{array}$

$\begin{array}{llllllllll}90 & \text { Common carp } & 0.11_{\mathrm{a}} & 0.10_{\mathrm{a}} & 0.60_{\mathrm{a}} & 0.84_{\mathrm{b}} & 49.8_{\mathrm{a}} & 65.6_{\mathrm{a}} & 0.86_{\mathrm{a}} & 1.22_{\mathrm{a}}\end{array}$

UMO

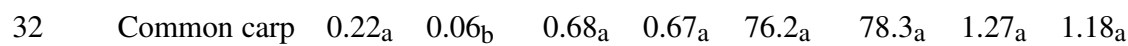

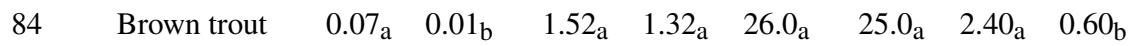

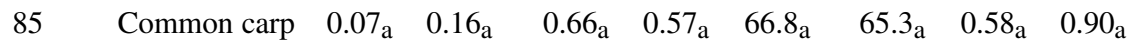

$\begin{array}{lllllllll}\text { Sauger } & 0.39 \mathrm{a} & 0.01_{\mathrm{b}} & 0.54_{\mathrm{a}} & 0.75_{\mathrm{a}} & 13.5_{\mathrm{a}} & 21.8_{\mathrm{b}} & 4.71_{\mathrm{a}} & 0.48_{\mathrm{b}}\end{array}$

LMS

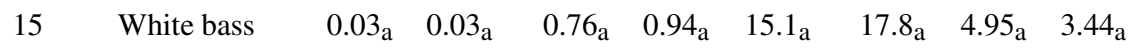

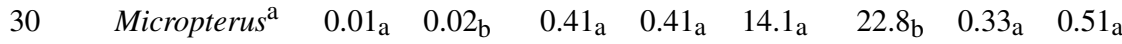

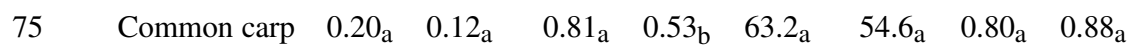

\section{UMS}

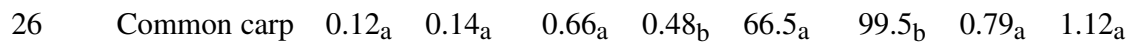

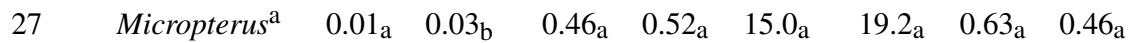

$\begin{array}{lllllllll}\text { Common carp } & 0.08_{\mathrm{a}} & 0.04_{\mathrm{a}} & 0.51_{\mathrm{a}} & 0.54_{\mathrm{a}} & 66.2_{\mathrm{a}} & 90.4_{\mathrm{a}} & 0.80_{\mathrm{a}} & 1.03_{\mathrm{a}}\end{array}$

$\begin{array}{llllllllll}72 & \text { Micropterus }^{\mathrm{a}} & 0.01_{\mathrm{a}} & 0.04_{\mathrm{b}} & 0.30_{\mathrm{a}} & 0.24_{\mathrm{a}} & 13.0_{\mathrm{a}} & 19.8_{\mathrm{b}} & 0.59_{\mathrm{a}} & 0.48_{\mathrm{a}}\end{array}$

$\begin{array}{lllllllll}\text { Common carp } & 0.21_{\mathrm{a}} & 0.05_{\mathrm{b}} & 0.35_{\mathrm{a}} & 0.46_{\mathrm{a}} & 58.8_{\mathrm{a}} & 79.3_{\mathrm{a}} & 2.37 \mathrm{a} & 0.97 \mathrm{~b}\end{array}$ 
TABLE V

(continued)

\begin{tabular}{|c|c|c|c|c|c|c|c|c|c|}
\hline \multirow{3}{*}{$\begin{array}{l}\text { Sub-basin } \\
\text { and station }\end{array}$} & \multirow[t]{3}{*}{ Taxon } & \multicolumn{8}{|c|}{ Element and collection year } \\
\hline & & \multicolumn{2}{|l|}{$\mathrm{Pb}$} & \multicolumn{2}{|l|}{$\mathrm{Se}$} & \multicolumn{2}{|l|}{$\mathrm{Zn}$} & \multicolumn{2}{|l|}{$\mathrm{Cu}$} \\
\hline & & 1986 & 1995 & 1986 & 1995 & 1986 & 1995 & 1986 & 1995 \\
\hline \multicolumn{10}{|c|}{ UMS (continued) } \\
\hline 73 & Common carp & $0.12_{\mathrm{a}}$ & $0.17 \mathrm{a}$ & $0.73_{\mathrm{a}}$ & $0.85 \mathrm{a}$ & $58.3_{\mathrm{a}}$ & $93.8_{\mathrm{b}}$ & $0.85 \mathrm{a}$ & $1.26_{\mathrm{a}}$ \\
\hline 74 & White sucker & $0.07 \mathrm{a}$ & $0.04 \mathrm{a}$ & $0.20 \mathrm{a}$ & $0.13_{\mathrm{b}}$ & $15.1_{\mathrm{a}}$ & $24.3_{\mathrm{b}}$ & $3.55_{\mathrm{a}}$ & $1.22 \mathrm{~b}$ \\
\hline 111 & Common carp & $0.29 \mathrm{a}$ & $0.17 \mathrm{a}$ & $0.59 \mathrm{a}$ & $0.58 \mathrm{a}$ & $91.4_{\mathrm{a}}$ & $102.0_{\mathrm{a}}$ & $1.05 \mathrm{a}$ & $1.11_{\mathrm{a}}$ \\
\hline 112 & Common carp & $0.08_{a}$ & $0.11_{\mathrm{a}}$ & $0.39 \mathrm{a}$ & $0.56_{\mathrm{b}}$ & $57.9 \mathrm{a}$ & $95.3_{\mathrm{b}}$ & $0.69_{\mathrm{a}}$ & $0.93 \mathrm{a}$ \\
\hline \multicolumn{10}{|l|}{ OHR } \\
\hline 23 & Micropterus $^{\mathrm{a}}$ & $0.07 \mathrm{a}$ & $0.04 \mathrm{a}$ & $0.35 \mathrm{a}$ & $0.38 \mathrm{a}$ & $14.0_{\mathrm{a}}$ & $24.3_{\mathrm{b}}$ & $0.22 \mathrm{a}$ & $0.58_{\mathrm{b}}$ \\
\hline 24 & Common carp & $0.25 \mathrm{a}$ & $0.30_{\mathrm{a}}$ & $0.53 \mathrm{a}$ & $0.67 \mathrm{a}$ & $73.1_{\mathrm{a}}$ & $81.9 \mathrm{a}$ & $0.62 \mathrm{a}$ & $1.46_{b}$ \\
\hline \multirow[t]{2}{*}{25} & Micropterus $^{\mathrm{a}}$ & $0.06_{a}$ & $0.04_{\mathrm{a}}$ & $0.35 \mathrm{a}$ & $0.30_{\mathrm{a}}$ & $16.2 \mathrm{a}$ & $22.4 \mathrm{a}$ & $0.37 \mathrm{a}$ & $0.48 \mathrm{a}$ \\
\hline & Common carp & $0.33_{\mathrm{a}}$ & $0.18 \mathrm{a}$ & $0.46_{a}$ & $0.43_{\mathrm{a}}$ & $67.9 \mathrm{a}$ & $74.0_{\mathrm{a}}$ & $0.75_{\mathrm{a}}$ & $1.15_{\mathrm{a}}$ \\
\hline \multirow[t]{2}{*}{67} & Micropterus $^{\mathrm{a}}$ & $0.01_{\mathrm{a}}$ & $0.03_{\mathrm{b}}$ & $0.38 \mathrm{a}$ & $0.45_{\mathrm{a}}$ & $14.6_{a}$ & $23.3_{\mathrm{b}}$ & $1.28 \mathrm{a}$ & $0.52_{\mathrm{b}}$ \\
\hline & Common carp & $0.24_{a}$ & $0.45 \mathrm{a}$ & $0.50_{\mathrm{a}}$ & $0.55 \mathrm{a}$ & $72.0_{\mathrm{a}}$ & $87.3 \mathrm{a}$ & $0.68 \mathrm{a}$ & $1.56_{\mathrm{b}}$ \\
\hline 68 & Common carp & $0.18_{\mathrm{a}}$ & $0.11_{\mathrm{a}}$ & $0.46_{a}$ & $0.62 \mathrm{a}$ & $62.2_{\mathrm{a}}$ & $60.8_{a}$ & $1.22_{\mathrm{a}}$ & $1.00_{\mathrm{a}}$ \\
\hline 70 & Micropterus $^{\mathrm{a}}$ & $0.07 \mathrm{a}$ & $0.22_{\mathrm{a}}$ & $0.37 \mathrm{a}$ & $0.43 \mathrm{a}$ & $13.0_{\mathrm{a}}$ & $20.4_{b}$ & $1.46_{\mathrm{a}}$ & $0.50_{\mathrm{b}}$ \\
\hline & Common carp & $0.12_{\mathrm{a}}$ & $0.13_{\mathrm{a}}$ & $0.36_{a}$ & $0.58 \mathrm{~b}$ & $59.3_{\mathrm{a}}$ & $75.1_{\mathrm{a}}$ & $0.98 \mathrm{a}$ & $0.93 \mathrm{a}$ \\
\hline ANOVA $F^{\mathrm{b}}$ & & 7.41 & & 17.19 & & 28.94 & & 8.14 & \\
\hline
\end{tabular}

${ }^{a}$ Largemouth, smallmouth, or spotted bass.

${ }^{\mathrm{b}}$ Degrees-of-freedom $=140,101$; all $p<0.01$.

The greatest 1995 concentrations (ca. $0.5-0.7 \mu \mathrm{g} \mathrm{g}^{-1}$ ) were therefore about half the concentrations associated with impaired heme synthesis in fish. Higher-level effects specifically associated with $\mathrm{Pb}$ at environmental concentrations have not been reported in fish; however, in combination with other elemental contaminants and environmental factors, effects on individual fish and fish populations have been documented (Farag et al., 1994, 1995; Woodward et al., 1997; Wildhaber et al., 2000).

\subsection{CADMIUM}

Cadmium is present in many common materials and is released to the environment from mining, smelting, and a variety of other sources and activities. In 1995, Cd was detected (ca. $0.05 \mu \mathrm{g} \mathrm{g}^{-1}$ ) in $49 \%$ of the samples from $91 \%$ of the stations sampled (Table III). Concentrations ranged from $<0.05 \mu \mathrm{g} \mathrm{g}^{-1}$ to about $0.5 \mu \mathrm{g}$ $\mathrm{g}^{-1}$, the latter in carp from Station 67 (Allegheny R.; Table III, Figure 3). Concen- 
trations were uniformly low $\left(<0.03 \mu \mathrm{g} \mathrm{g}^{-1}\right)$ in all samples from the reference site. In contrast, comparatively high concentrations of $\mathrm{Cd}\left(>0.15 \mu \mathrm{g} \mathrm{g}^{-1}\right)$, as individual samples, station means, or both, were detected at NCBP Stations 24 (Ohio R. at Marietta, OH), 25 (Cumberland R.), 90 (Kansas R.), 78 (Verdigris R.), 73 (Des Moines R.), and 30 (White R.). At all of these sites except Station 30, where one relatively high value occurred in largemouth bass, the highest concentrations were in carp (Figure 3). Cd concentrations at Stations 67, 78, and 24 have been among the greatest in previous NCBP collections (May and McKinney, 1981; Lowe et al., 1985; Schmitt and Brumbaugh, 1990; Schmitt et al., 1999b). Station 78 has a long history of contamination by metals from the Tri-State Mining District of Missouri, Oklahoma, and Kansas, where Zn and other metals were mined for many years and where there are abandoned mines and ore-processing facilities (May and McKinney, 1981; Pita and Hyne, 1975; Wildhaber et al., 2000). Goldstein and DeWeese (1999) reported that concentrations of Cd in carp collected in 1994 from the RRN averaged $0.22 \mu \mathrm{g} \mathrm{g}^{-1} \mathrm{dw}$ (about $0.07 \mu \mathrm{g} \mathrm{g}^{-1} \mathrm{ww}$ ), a level exceeded at most MRB sites but which was greater than all samples from the reference site (Figure 3).

Schmitt et al. (1999b) noted that Cd concentrations tended to be greater in carp than in other taxa, a trend that held through 1995 (Figure 3). Concentrations of Cd in carp differed significantly among stations and sub-basins, but not between the NAWQA and NCBP sites. Concentrations were significantly greater at NCBP and NAWQA sites than at the reference site (Table IV), where levels were < LOD in both samples (Figure 3). Greatest mean concentrations of Cd in carp occurred in the OHR and ARR sub-basins, and neither NAWQA Study Unit (MSE, EIB) differed significantly from its respective sub-basin (LMS, UMS; Table IV). Concentrations of $\mathrm{Cd}$ in bass ( $95 \%$ censored) were not analyzed statistically.

Relative to previous collections, concentrations of Cd in carp increased at Stations 67 and 90 (1984) and decreased at Stations 32 (Missouri R. at Garrison Dam, ND) and 79 (Canadian R.). Concentrations also increased in largemouth bass at Station 30 (White R.), white bass at Stations 15 and 25, and in other taxa at stations in the Upper Missouri River (UMO) sub-basin-goldeye at Station 86 (James R.), sauger at Station 85 (Yellowstone R.), and brown trout at Station 84 (Big Horn R.). Carp were collected at Stations 85 and 86 in both 1986 and 1995, but Cd concentrations were low in all samples (Figure 3).

Whole-organism Cd concentrations of $2 \mu \mathrm{g} \mathrm{g}^{-1}$ are indicative of contamination, levels of $5 \mu \mathrm{g} \mathrm{g}^{-1}$ are considered hazardous to the organism, and dietary levels of 13-15 $\mu \mathrm{g} \mathrm{g}^{-1}$ represent a hazard to higher trophic levels (Eisler, 1985; Jarvinen and Ankley, 1999). Even the greatest 1995 concentrations were well below the lowest of these toxicity thresholds. 


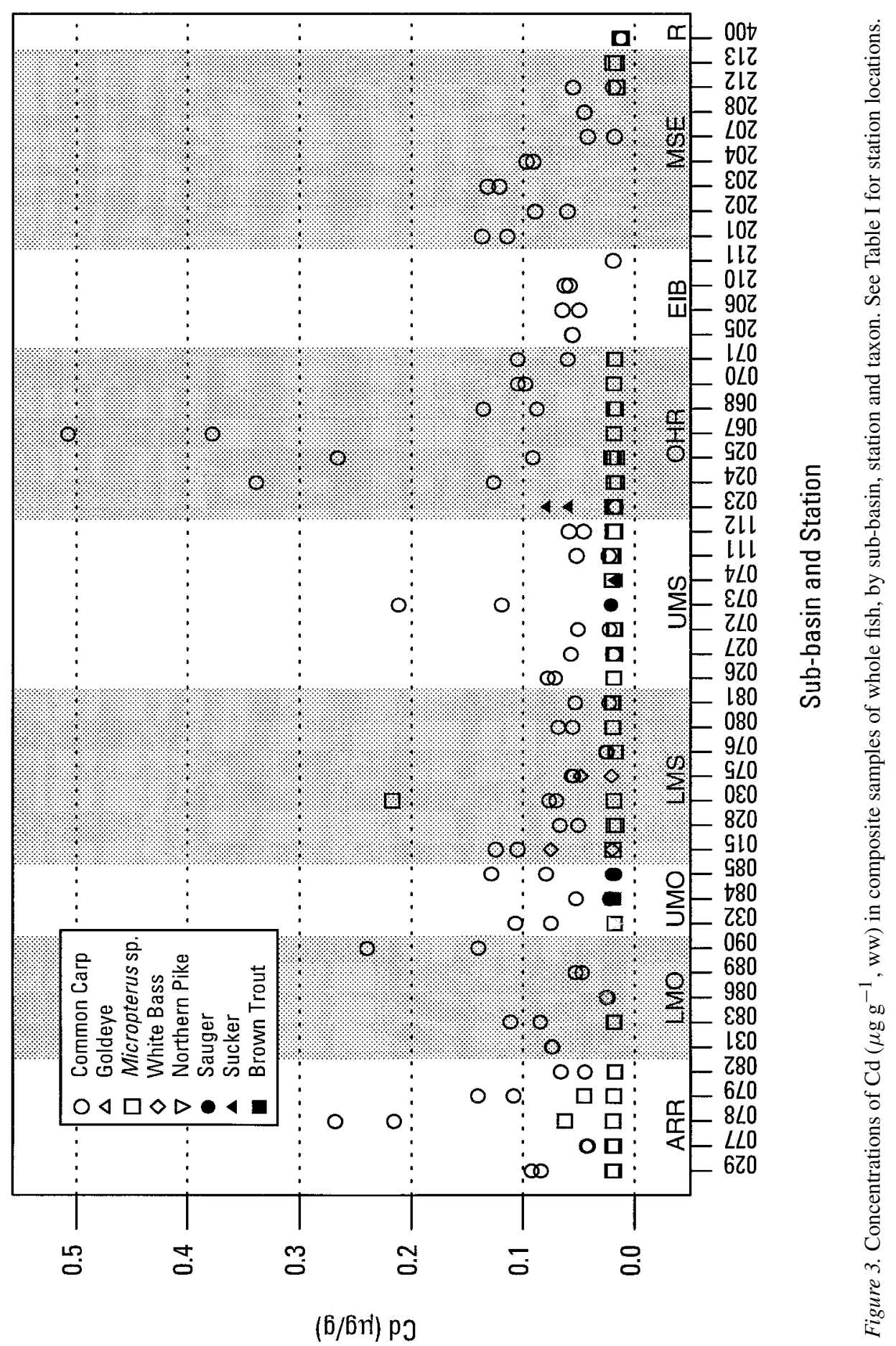




\subsection{SELENiUm}

Selenium is released to the environment from the combustion of fossil fuels and can be leached from arid, seleniferous soils by irrigation (Lemly, 1996). In 1995, Se was detected $\left(>0.02 \mu \mathrm{g} \mathrm{g}^{-1}\right)$ in all but two samples (white sucker from Station 74, carp from Station 400; Figure 5). Except for Station 77 (Arkansas R. at John Martin Reservoir, $\mathrm{CO}$ ), concentrations were relatively low; they ranged from barely detectable (ca. $0.20 \mu \mathrm{g} \mathrm{g}^{-1}$ ) to $1.40 \mu \mathrm{g} \mathrm{g}^{-1}$ (Figure 4). In contrast, concentrations were 3.5-4.7 $\mu \mathrm{g} \mathrm{g}^{-1}$ in all samples (carp and largemouth bass) from Station 77 (Figure 4, Table III). Nationally, the maximum 1986 concentration $\left(3.4 \mu \mathrm{g} \mathrm{g}^{-1}\right)$ was also in carp from Station 77 (Schmitt et al., 1999b). In 1995, Se concentrations exceeded $1.0 \mu \mathrm{g} \mathrm{g}^{-1}$ in samples from only two other stations: NCBP Station 84 (Big Horn R.), where concentrations were $1.0-1.4 \mu \mathrm{g} \mathrm{g}^{-1}$ in all samples (carp and brown trout); and NCBP Station 78 (Verdigris R.), where concentrations were about $1.2 \mu \mathrm{g} \mathrm{g}^{-1}$ in both 1995 samples of carp but were lower $\left(0.7 \mu \mathrm{g} \mathrm{g}^{-1}\right)$ in largemouth bass (Figure 4). Concentrations at Station 84 were also comparatively high in 1986 (Table V; Schmitt et al., 1999b). Concentrations at the West Virginia reference site were $0.27-0.30 \mu \mathrm{g} \mathrm{g}^{-1}$ in largemouth bass and $<0.12-0.29 \mu \mathrm{g} \mathrm{g}^{-1}$ in carp (Figure 4), the latter only slightly lower than the $1.18 \mu \mathrm{g} \mathrm{g}^{-1} \mathrm{dw}$ (about $0.35 \mu \mathrm{g} \mathrm{g}^{-1} \mathrm{ww}$ ) mean for whole carp collected from the RRN in 1994 (Goldstein and DeWeese, 1999). Both are similar to concentrations in fish from many rural MRB sites (Figure 4).

There were no censored values for Se in bass, and only one value was < LOD in carp. Se concentrations in both carp and bass differed significantly among stations and sub-basins in both carp and bass, but differed among programs only in bass (Table IV). NCBP sub-basins with the greatest concentrations (ARR, UMO, and LMO) differed significantly from all others and from the reference site, and concentrations at the reference site were significantly lower than in all sub-basins (Table IV). Concentrations in both NAWQA Study Units (MSE and EIB) were significantly greater than in their respective NCBP sub-basin (UMS and LMS; Table IV). Overall, Se concentrations in carp did not differ significantly between NCBP and NAWQA stations, but both averaged much greater than the reference site (Table IV). In bass, geographic trends were similar; however, concentrations in the MSE Study Unit (two stations) were significantly, but not substantially, different from those in LMS bass, but were lower than the NCBP sites as a group (Table IV).

Concentrations of Se in carp increased significantly from 1986 to 1995 at Stations 70 (Ohio R. at Metropolis, IL), 78 (Verdigris R.), 79 (Canadian R.), 90 (Kansas R.), and 112 (Mississippi R. at Dubuque, IA) while decreasing at Stations 26 (Illinois R.), and 75 (Mississippi R. at Cape Girardeau, MO; Table V). Concentrations also decreased in white sucker from Station 74 (Mississippi R. at Little Falls, MN), but there were no significant changes in bass (Table V). As noted previously, the relatively high concentrations of Se in brown trout from Station 84 


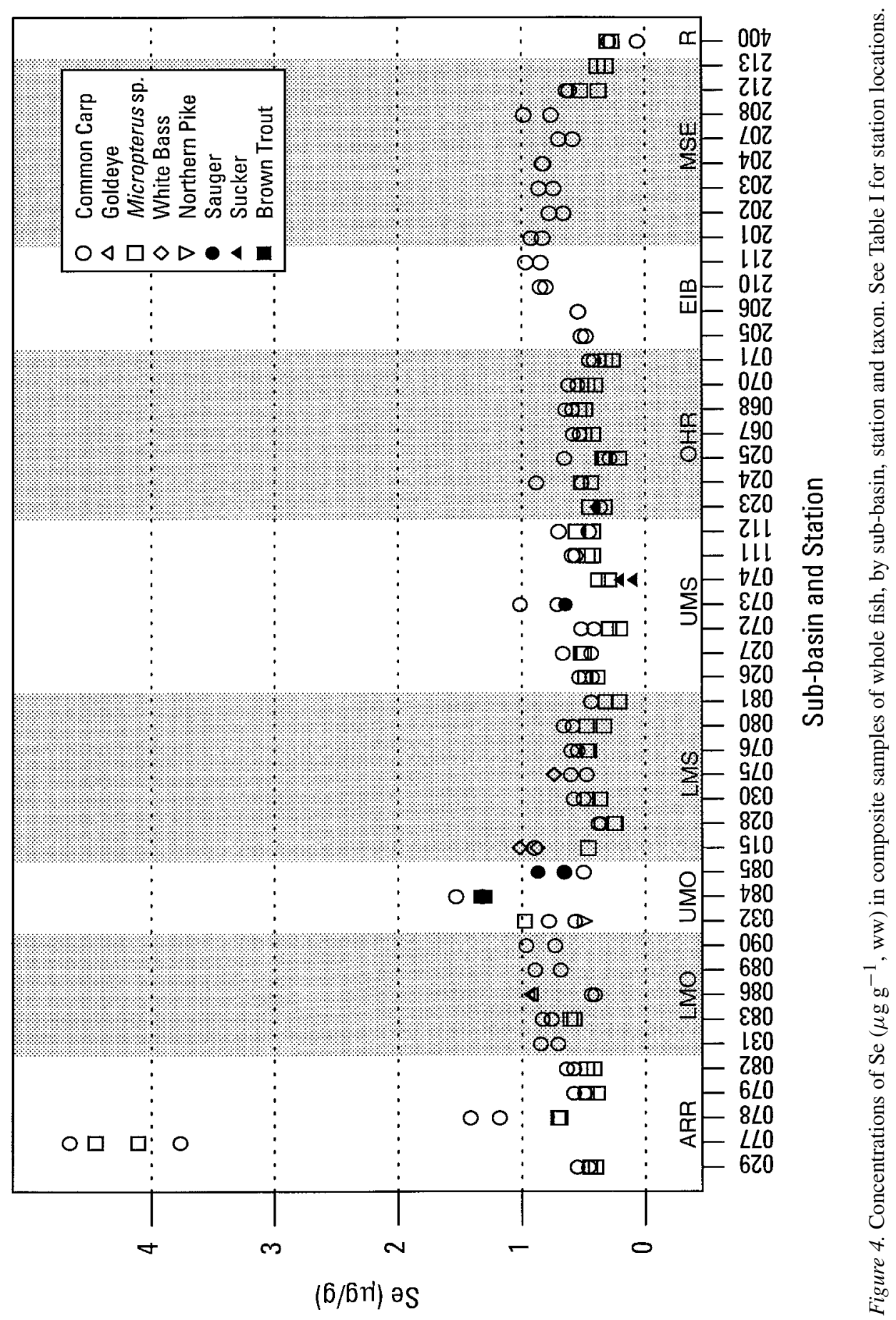


remained unchanged from 1986 to 1995 (Table V). In contrast, Se concentrations in carp at Station 77 increased by $25 \%$ from 1986 to 1995. Although this change was not statistically significant, it should be noted that concentrations at this site have been increasing since the 1970s (May and McKinney, 1981; Lowe et al., 1985; Schmitt and Brumbaugh, 1990; Schmitt et al., 1999b). Nationally, the geometric mean concentration of Se in fish (all NCBP stations) declined slightly from 19781981 to 1984 (Schmitt and Brumbaugh, 1990), but increased slightly from 1984 to 1986 (Schmitt et al., 1999).

The bioaccumulation of Se can become problematic for fish and wildlife when arid, seleniferous soils are leached by irrigation, as it has in parts of the western U.S. (Lemly, 1996). Se bioaccumulation to harmful levels has also been noted in cooling reservoirs associated with coal-fired power plants (Baumann and Gillespie, 1986). According to Lemly (1996), the whole-fish threshold for Se toxicity (to the fish) is about $4 \mu \mathrm{g} \mathrm{g}^{-1}$ dry weight $\left(0.8 \mu \mathrm{g} \mathrm{g}^{-1} \mathrm{ww}\right)$, and for the protection of piscivorous wildlife it is about $3 \mu \mathrm{g} \mathrm{g}^{-1}$ dry weight $\left(0.6 \mu \mathrm{g} \mathrm{g}^{-1} \mathrm{ww}\right)$. The carp from Stations 77, 78, and 84 exceeded both values in 1995. So also did the largemouth bass from Station 77 and one sample of carp from each of NCBP Stations 32 (Missouri R. at Garrison Dam, MT), 89 (Platte R.), 90 (Kansas R.), and 85 (Yellowstone R.); and NAWQA Stations 201 (Big Sunflower R.), 211 (Cedar R.), and 208 (Cache R.). Both samples of carp from NCBP Stations 15 (Mississippi R. at Luling, LA) and 86 (James R.) exceeded $0.6 \mu \mathrm{g} \mathrm{g}^{-1}$ (Figure 4).

\subsection{ARSENIC}

Elevated environmental concentrations of As typically originate as byproducts of metallurgical processes, from the combustion of fossil fuels, and from the use of arsenical pesticides and defoliants. In 1995, concentrations of As were > LOD $\left(0.2-0.3 \mu \mathrm{g} \mathrm{g}^{-1}\right)$ in only $28 \%$ of the samples from $48 \%$ of the stations sampled (Table III). Greatest concentrations (0.30-0.52 $\mu \mathrm{g} \mathrm{g}^{-1}$ in one or more samples) were found at NCBP Stations 78 (Verdigris R.), 79 (Canadian R.), 29 (Arkansas R. at Keystone Reservoir, OK), 15 (Mississippi R. at Luling, LA), 80 (Yazoo R.), 26 (Illinois R.), 76 (Mississippi R. at Memphis), and 75 (Mississippi R. at Cape Girardeau, MO; Table III, Figure 5). Except for one carp sample from Station 76, these greatest values all occurred in largemouth bass (Figure 5). At Station 25 (Cumberland R.), where two species of bass were collected, concentrations were about the same in both: $0.22-0.29 \mu \mathrm{g} \mathrm{g}^{-1}$ in largemouth bass, $<0.21-0.29 \mu \mathrm{g}$ $\mathrm{g}^{-1}$ in spotted bass (Figure 5). In addition to Station 76, concentrations were also comparatively high $\left(>0.2 \mu \mathrm{g} \mathrm{g}^{-1}\right)$ in at least one carp sample from Stations 29 and 77 (Arkansas R. at John Martin Reservoir, CO), 80 (Yazoo R.), 24 (Ohio R. at Marietta, $\mathrm{OH}$ ), and 71 (Tennessee R.). Arsenic concentrations in carp collected from the RRN in 1994 averaged $1.18 \mu \mathrm{g} \mathrm{g}^{-1} \mathrm{dw}$ (about $0.35 \mu \mathrm{g} \mathrm{g}^{-1} \mathrm{ww}$; Goldstein and DeWeese, 1999), which is greater than all but the highest concentrations in 
MRB carp (Figure 5). Conversely, As concentrations were < LOD (ca. $0.12 \mu \mathrm{g}$ $\mathrm{g}^{-1}$ ) in all samples from all NAWQA sites in the MRB and from the reference site.

Concentrations of As in NCBP fish have historically been greatest at stations outside the MRB (i.e., in the Colorado River basin and the Great Lakes - Schmitt and Brumbaugh, 1990; Schmitt et al., 1999b). One possible reason is the tendency of As to accumulate in the planktivorous fishes (corregonine salmonids, clupeids, etc.) collected in these regions, which were not targeted in 1995. The lone exception was Station 69 (Ohio R. at Cincinnati, OH), which was not sampled in 1995. Temporal trends for As were not tested statistically due to the large number of censored values. Nevertheless, concentrations in carp and bass were lower in 1995 than in 1986 at Station 70 (Ohio R. at Metropolis, IL) but increased in other species at Stations 74 (Mississippi R. at Little Falls, MN), 84 (Big Horn R.), and 85 (Yellowstone R.; data not shown).

Because As tends to accumulate in planktivorous species (and also sculpins, Cottus spp.) to a greater degree than in other fishes (Hunter et al., 1981; Schmitt and Brumbaugh, 1990; Wagemann et al., 1978) and can be further accumulated by piscivores (Hunter et al., 1981), the occurrence of planktivorous fishes at some sites and the dynamics of the ecosystems in which they occur may confound trends for As. The comparatively high concentrations of As in largemouth bass in the southern parts of the MRB, especially in the storage impoundments and the river systems containing them, may therefore be as much or more a function of the occurrence of planktivorous clupeids (i.e., Dorosoma spp.) as a reflection of environmental concentrations. In addition, large amounts of arsenical herbicides and defoliants are used in cotton farming and in other applications in the MRB, and As is released along with $\mathrm{Se}, \mathrm{Hg}$, and other elements during the combustion of coal. Large amounts are also released during the smelting of metals. Coal-fired power plants are distributed throughout the MRB, and there are numerous active and inactive smelters (Schmitt et al., 2002). Collectively, these facts may explain the occurrence of comparatively high concentrations of As in fish from some parts of the MRB and the RRN.

Arsenic concentrations in freshwater fish (ca. $0.5-1 \mu \mathrm{g} \mathrm{g}^{-1}$ ) are low relative to naturally occurring levels in marine fishes and invertebrates, and are typically less than levels associated with adverse impacts in laboratory studies (Jarvinen and Ankley, 1999). Concentrations in the $1995 \mathrm{MRB}$ samples $\left(<0.6 \mu \mathrm{g} \mathrm{g}^{-1}\right)$ are probably not a hazard to either the fish or to higher trophic level organisms that might consume them (U.S. EPA, 1984; Eisler, 1994). In addition, As is largely accumulated by fish as organoarsenicals, which are less toxic than inorganic forms (Maeda, 1994; Law, 1996).

\subsection{ZINC AND COPPER}

The ICPES elemental scan yielded data for some analytes of marginal environmental significance. Although all can be toxic to fish under certain conditions, 


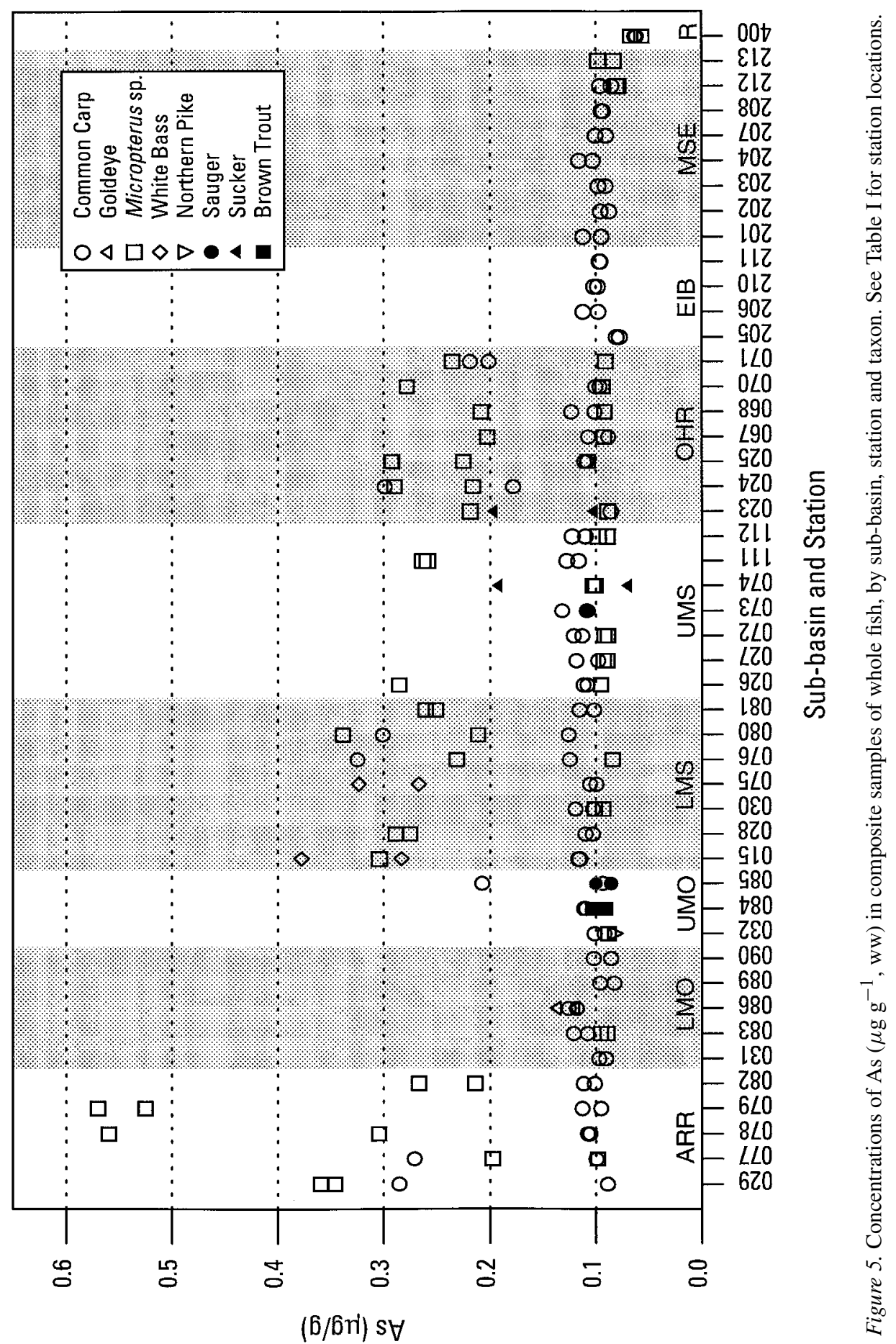


many (including $\mathrm{Cu}$ and $\mathrm{Zn}$ ) are also essential trace elements that do not normally accumulate in environmentally exposed fish to concentrations that represent a threat to higher-level organisms, even in heavily contaminated areas (Schmitt et al., 1993; 2002). Many elements accumulate preferentially in specific organs and tissues (e.g., May and McKinney, 1977; Harrison and Klaverkamp, 1990; Farag et al., 1995; Goldstein et al., 1996; Goldstein and DeWeese, 1999; Taylor et al., 2000) such as liver $(\mathrm{Zn}, \mathrm{Cu}$, etc.), kidney $(\mathrm{Cd})$, bone $(\mathrm{Pb})$, gill $(\mathrm{Cu})$, or muscle $(\mathrm{Hg})$. The accumulation of these elements also differs greatly among taxa; for example, carp seem to accumulate $\mathrm{Zn}$ to a greater extent than other fishes (Lowe et al., 1985; Schmitt and Brumbaugh, 1990, Schmitt et al., 1999b), and white perch (Morone americana) accumulate $\mathrm{Cu}$ in their livers in a condition analogous to Wilson's disease in humans (Bunton et al., 1987). Data for the elements not reported here can be obtained at <http://www.cerc.usgs.gov/data/data.htm $>$.

\subsubsection{Zinc}

Zinc is an essential element that is released to the environment from mining, smelting, and a variety of other activities and sources (May and McKinney, 1977; Schmitt et al., 2002). In 1995, Zn was detected in all samples (Table III). Concentrations in carp ranged from $16.7 \mu \mathrm{g} \mathrm{g}^{-1}$ to $150.0 \mu \mathrm{g} \mathrm{g}^{-1}$. Greatest concentrations in carp (>90 $\mu \mathrm{g} \mathrm{g}^{-1}$ ) occurred at NCBP Stations 79 (Canadian R.) and 84 (Big Horn R.); at two OHR stations - 67 (Allegheny R.) and 24 (Ohio R. at Marietta, OH); and at five UMR stations - 26 (Illinois R.), 112 (Mississippi R. at Dubuque, IA), 27 (Mississippi R. at Guttenburg, IA), 73 (Des Moines R.), and 111 (Mississippi R. at Lake City, MN); and at one NAWQA site in the EIB Study Unit - Station 210 (Iowa R.; Figure 6). The lowest was at Station 23 (Kanawha R.). At the reference site, $\mathrm{Zn}$ concentrations in carp were also low (37.3-44.3 $\left.\mu \mathrm{g} \mathrm{g}^{-1}\right)$ in both samples (Figure 6). Concentrations in carp collected from the RRN in 1994 by Goldstein and DeWeese (1999) were higher; they averaged $216 \mu \mathrm{g} \mathrm{g}^{-1} \mathrm{dw}$ (about $64.8 \mu \mathrm{g}$ $\mathrm{g}^{-1} \mathrm{ww}$ ), a concentration typical of most MRB stations (Figure 6). In contrast to $\mathrm{Pb}$, concentrations of $\mathrm{Zn}$ in carp were greater at many MRB sites than in those collected in 1992 from the Mississippi River near the smelter at Herculanuem, MO by Schmitt et al. (2002). In taxa other than carp, Zn concentrations ranged from $13.7 \mu \mathrm{g} \mathrm{g}^{-1}$ in smallmouth bass from Station 74 (Mississippi R. at Little Falls, MN) to $41.6 \mu \mathrm{g} \mathrm{g}^{-1}$ in goldeye from Station 86 (James R.; Table III, Figure 6). Relative to carp, $\mathrm{Zn}$ concentrations in bass were uniformly low; although one sample of largemouth bass from Station 79 (Canadian R.) contained $37.3 \mu \mathrm{g} \mathrm{g}^{-1}$, all others were between 13.0 and $30.0 \mu \mathrm{g} \mathrm{g}^{-1}$ (Figure 6). Concentrations were slightly greater in spotted bass (23.9-25.6 $\left.\mu \mathrm{g} \mathrm{g}^{-1}\right)$ than in largemouth bass (19.9-20.4 $\mu \mathrm{g} \mathrm{g}^{-1}$ ) from Station 25.

Concentrations of $\mathrm{Zn}$ in carp differed significantly among stations and subbasins, but not among programs (Table IV). Levels were generally greatest in the UMS, UMO, and ARR sub-basins and lowest in the OHR, LMO, and LMS sub- 


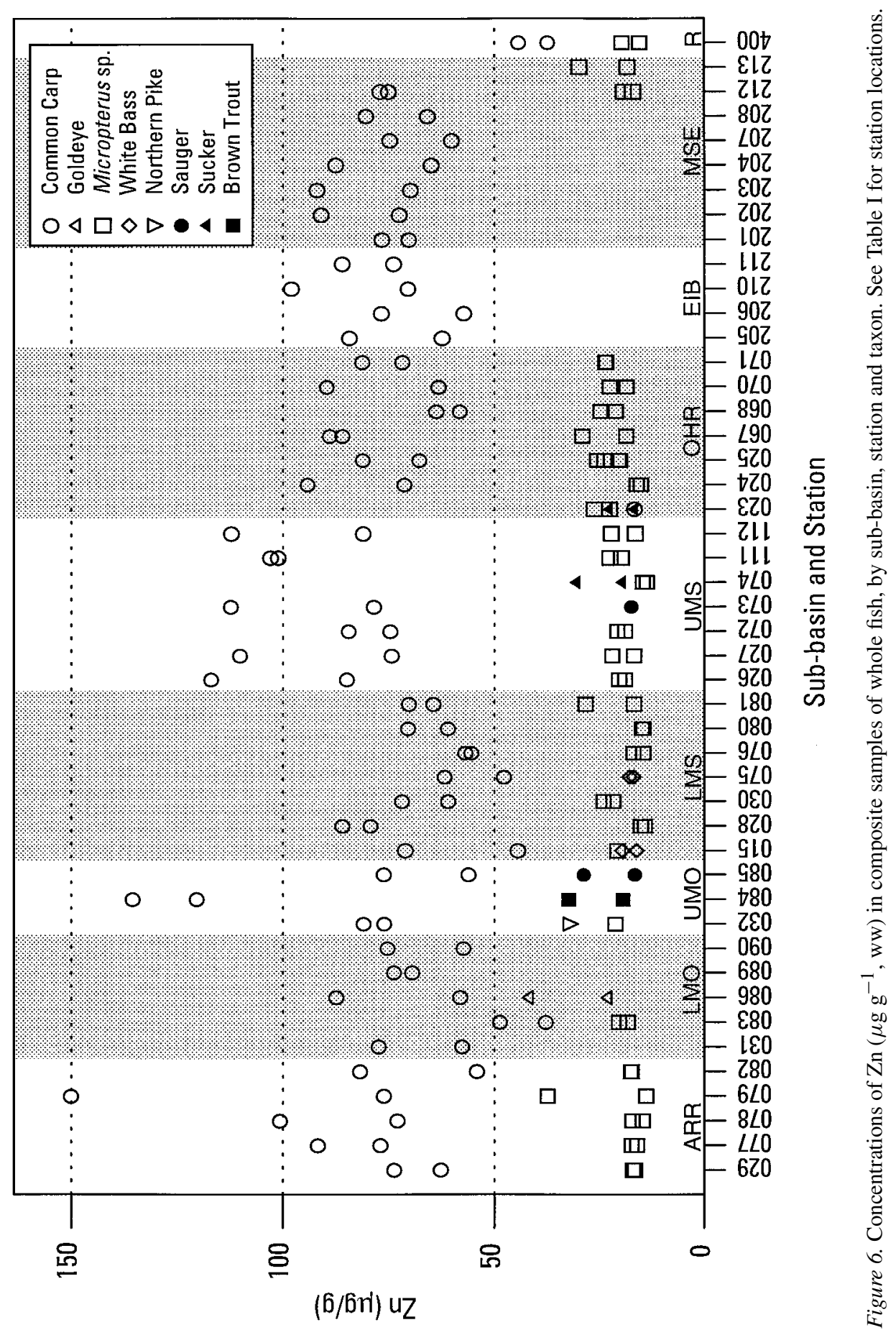


basins (Table IV). Concentrations of $\mathrm{Zn}$ in bass did not differ significantly among stations, sub-basins, or programs (Table IV).

Concentrations of $\mathrm{Zn}$ in carp increased significantly from 1986 to 1995 at Stations 26 (Illinois R.), 73 (Des Moines R.), 79 (Canadian R.), and 112 (Mississippi R. at Dubuque, IA); in bass at Stations 30 (White R.), 72 (Wisconsin R.), 23 (Kanawha R.), 67 (Allegheny R.), and 70 (Ohio R. at Metropolis, IL). Increases were also significant in white sucker at Station 74 (Mississippi R. at Little Falls, $\mathrm{MN}$ ), sauger at Station 85 (Yellowstone R.), and mooneye at Station 86 (James R.; Table V). Concentrations of $\mathrm{Zn}$ in carp from many MRB sites exceeded levels associated with adverse effects in other taxa in laboratory studies (Jarvinen and Ankeley, 1999).

\subsubsection{Copper}

Like $\mathrm{Zn}, \mathrm{Cu}$ is an essential element that occurs naturally and is also released from a variety of sources. Consequently, $\mathrm{Cu}$ was detected by ICPES in all samples (Table III). In contrast to $\mathrm{Zn}$, however, there were fewer clearly evident trends in the 1995 results for $\mathrm{Cu}$. Concentrations ranged from 0.35 to $3.84 \mu \mathrm{g} \mathrm{g}^{-1}$ and were greatest in white bass from NCBP Station 15 (Mississippi R. at Luling, LA; Table III, Figure 7). Concentrations were also higher than most $\left(>1.5 \mu \mathrm{g} \mathrm{g}^{-1}\right)$ in white bass from Station 75 (Mississippi R. at Cape Girardeau, MO), and in carp from Stations 30 (White R.), 89 (Platte R.), 67 (Allegheny R.) and 24 (Ohio R. at Marietta, $\mathrm{OH}$; Figure 7). Copper concentrations at the reference site were about $1.0 \mu \mathrm{g} \mathrm{g}^{-1}$ in carp; in largemouth bass they were $0.35-0.66 \mu \mathrm{g} \mathrm{g}^{-1}$ (Figure 7). At Station 25, concentrations were slightly greater in spotted bass $(0.52-0.67 \mu \mathrm{g}$ $\left.\mathrm{g}^{-1}\right)$ than in largemouth bass $\left(0.43-0.52 \mu \mathrm{g} \mathrm{g}^{-1}\right)$. Goldstein and DeWeese (1999) reported that $\mathrm{Cu}$ averaged $3.02 \mu \mathrm{g} \mathrm{g}^{-1} \mathrm{dw}$ (about $0.9 \mu \mathrm{g} \mathrm{g}^{-1} \mathrm{ww}$ ) in carp collected from the RRN in 1994, which is slightly lower than most of the 1995 MRB values but about the same as those in carp from the reference site (Figure 7). Although high compared to other species, the 1995 concentrations in white bass from Station 15 were nevertheless about 10-fold lower than those typical of the congeneric white perch (Morone Americana) from Atlantic coastal rivers and estuaries (Bunton et al., 1987; Schmitt and Brumbaugh, 1990).

Concentrations of $\mathrm{Cu}$ in bass differed significantly, but the differences were small; and differences among stations and programs were not statistically significant (Table IV). Concentrations were generally lowest at the reference site and in the ARR, UMS LMS, and OHR sub-basins, and levels in the MSE Study Unit were significantly greater than in the LMS sub-basin (Table IV). In contrast to bass, no geographic differences in carp were statistically significant (Table IV).

Relative to 1986, Cu concentrations increased significantly in carp at Station 79 (Canadian R.), 24 (Ohio R. at Marietta, OH), and 67 (Allegheny R.), and in bass at Station 23 (Kanawha R.). Concentrations decreased in carp at Station 72 (Wisconsin R.), bass at Stations 67 and 70 (Ohio R. at Metropolis, IL), white sucker at Station 74 (Mississippi R. at Little Falls, MN), brown trout at Station 84 (Big Horn 


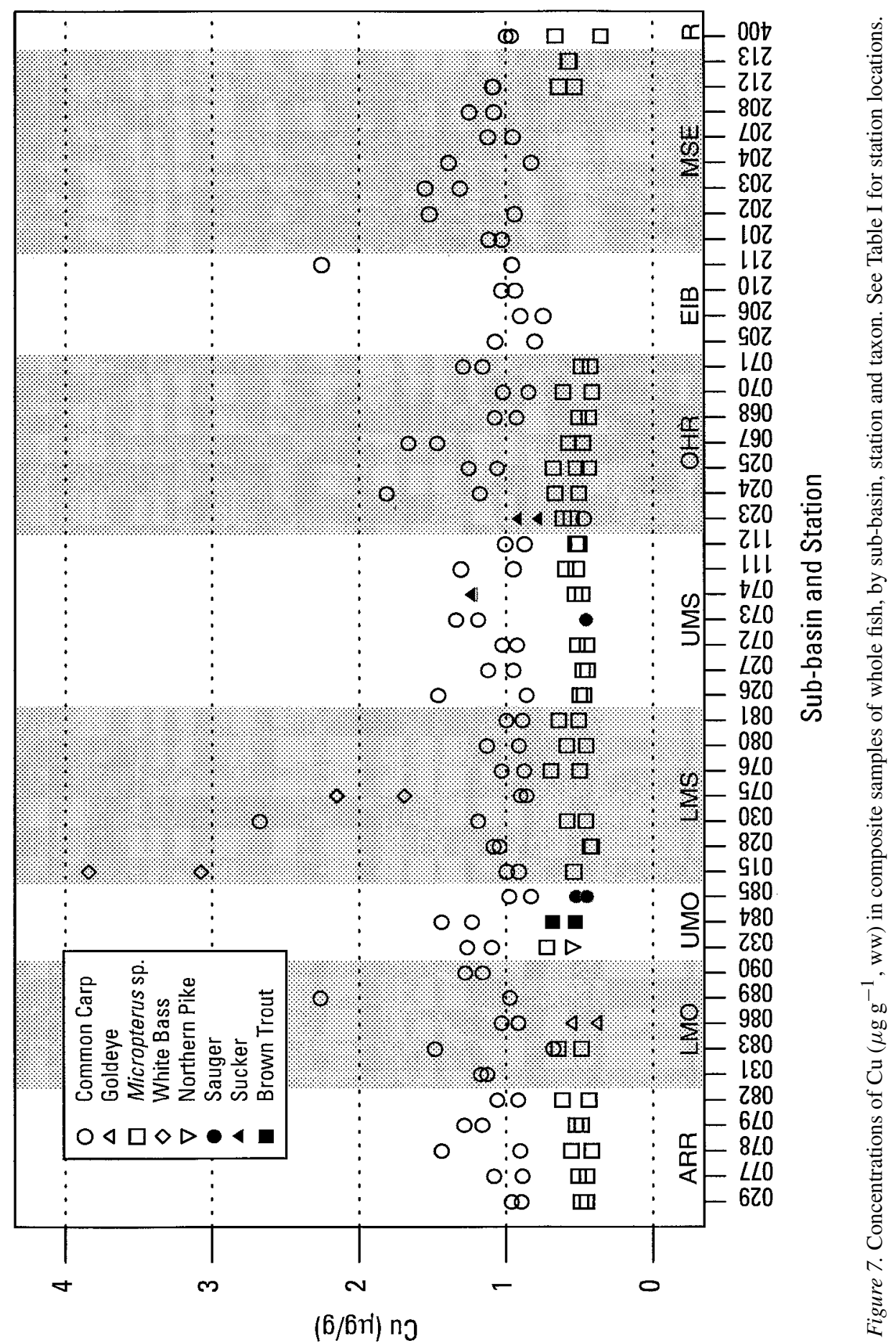


R.), and sauger at Station 85 (Yellowstone R.; Table V). On a dry-weight basis, the $1995 \mathrm{Cu}$ concentrations in the two samples of brown trout from Station 84 (1.83$2.52 \mu \mathrm{g} \mathrm{g}^{-1}$ ) were within the range of values reported for this species collected from reference sites in Montana, but were 2- to 3-fold lower than concentrations associated with adverse effects on brown trout health and physiology in fish from mining-contaminated sites (Farag et al., 1995).

\section{Summary and Conclusions}

Several trends were evident from the results of this study. First, concentrations of most of the elements examined were lower in both carp and bass from the West Virginia reference site than from the rivers and larger impoundments in the MRB. Although the fish from the reference site were slightly smaller and younger than those from some sites in the MRB, the concentration differences were greater than would be expected based solely on fish size. Instead, these differences probably reflect a relative lack of pollution sources relative to the MRB rivers, which are all contaminated to some degree by agricultural, municipal, and industrial activities, and ecosystem differences between the sites. In addition, concentrations of all the elements reported here except $\mathrm{Pb}$ and $\mathrm{Cu}$ were lower in carp from the reference site than in those from the RRN (Brigham et al., 1998; Goldstein and DeWeese, 1999). Although there are many possible explanations for this finding, a potentially important one is the location of the RRN basin (North-Central U.S.) compared to the Potomac River basin (Eastern U.S.) with respect to atmospheric sources of $\mathrm{Pb}$ and other elemental contaminants. In contrast, concentrations of As were greater in carp from the RRN than from most sites in the MRB and were much greater than at the reference site, which suggests agricultural, municipal, or natural sources, singly or in combination.

Overall, there were few differences between NCBP sites, which are typically situated on large rivers and their impoundments, and the NAWQA sites, which generally represent lower-order rivers and streams. It should be noted, however, that the degree to which the results (i.e., temporal and geographic differences or not) documented here may have been influenced by fish size and age was not determined. The accumulation of $\mathrm{Hg}$ with increasing age and body size in predatory fish has been well documented (Wiener et al., 2002) and may also occur for As and Se; however, such relationships have been explored to a far lesser degree for these and other elemental contaminants than for $\mathrm{Hg}$.

Of the elemental contaminants in fish reported here, only Se occurred at potentially problematic concentrations relative to current values for evaluating risk to fish and wildlife. Concentrations of Se were comparatively high (ca. $5 \mu \mathrm{g} \mathrm{g}^{-1}$ ) in all samples from Station 77 (Arkansas R. at John Martin Reservoir, CO), where levels have been high in the past. Although $25 \%$ higher than when last sampled in 1986, the increase at Station 77 was not statistically significant $(p>0.05)$. 
Nevertheless, Se concentrations at this site have been increasing for two decades. The Upper Arkansas River basin contains seleniferous rocks and soils that have been leached by irrigation. Slightly elevated Se concentrations were also present in fish from several sites in the UMO sub-basin, where there are also seleniferous rocks and soils and irrigated agriculture.

Differences among taxa were highly evident. Concentrations of $\mathrm{Cd}$ and $\mathrm{Zn}$ tended to be greatest in carp than in all other species analyzed. Nevertheless, $\mathrm{Cd}$ concentrations in carp were comparatively high $\left(>0.2 \mu \mathrm{g} \mathrm{g}^{-1}\right)$ only at one site in each of the ARR, LMO, LMS, and UMS sub-basins, and at two stations in the OHR sub-basin. Zn concentrations were more variable, and few trends were evident. $\mathrm{Pb}$ concentrations were also greatest in carp, but were generally low compared to fish from heavily contaminated sites (cf. Schmitt et al., 2002); levels were $<0.2 \mu \mathrm{g} \mathrm{g}^{-1}$ at all stations except one each in the MSE Study Unit and the LMO, UMO, and LMS sub-basins; two in the UMS and ARR sub-basins; and five stations in the OHR sub-basin. At one of the latter (Station 67, Allegheny River at Natrona, PA), concentrations of $\mathrm{Pb}, \mathrm{Cd}$, and $\mathrm{Zn}$ increased from 1986 to 1995. Concentrations of As were greatest in bass from sites in the ARR sub-basin, and may be at least partly related to the structure of the reservoir ecosystems represented by those sites. $\mathrm{Cu}$ concentrations were greatest in white bass and carp, but there were no temporal or geographic trends. At the one site at which largemouth bass and spotted bass of similar size were analyzed, differences in the concentrations of the elements reported here were small.

\section{Acknowledgements}

The information reported here was part of a pilot study designed to field-test and validate chemical and biological markers for use in the USGS-BEST program, which was managed at various times by W. Willford, C. Bunck, and T. Bartish. The study was conducted in partnership with the U.S. Fish and Wildlife Service (FWS) Division of Environmental Contaminants and the USGS-NAWQA program. Laboratory analyses were performed by the Research Triangle Institute, Research Triangle Park, NC through a contract managed by the FWS-Patuxent Analytical Control Facility (PACF) in Laurel, MD; J. Moore of PACF was particularly helpful. Field portions of the study were conducted under the supervision of FWS Environmental Contaminants Specialists and USGS-NAWQA biologists stationed throughout the MRB. Fish from the reference site were collected by personnel of the USGS-Leetown Science Center in Kearneysville, WV. B. Wright and M. Ellersieck assisted with statistical analyses. D. Tillitt, T. Kubiak, R. DeWeese, S. Smith, W. Bryant, T. Bartish, V. Blazer, T. Gross, J. Moore, P. MacDonald, M. Chandramoulesswaran, R. Jung, R. Lipkin, S. Finger, G. Dethloff, D. Nicks, and A. Donahue assisted with various aspects of the study. W. Brumbaugh and T. May 
reviewed an earlier version of this paper, and three anonymous reviewers made many useful suggestions.

\section{References}

Baumann, P. C. and Gillespie R. B.: 1986, 'Selenium bioaccumulation in gonads of largemouth bass and bluegill from three power plant cooling reservoirs', Environ. Toxicol. Chem. 5, 695-701.

Biomonitoring of Environmental Status and Trends Program (BEST): 1996, Summary Report from a Workshop on Selection of Tier 1 Bioassessment Methods, U.S. Department of the Interior, National Biological Service, Washington, D.C., Information and Technology Report 7, 55 p.

Brigham, M. E., Goldstein, R. M. and Tornes, L. H.: 1998, Trace Elements and Organic Chemicals in Stream-Bottom Sediments and Fish Tissues, Red River of the North Basin, Minnesota, North Dakota, and South Dakota, 1992-1995, U.S. Geological Survey, Water-Resources Investigations Report 97-4043, Mounds View, MN, 32 p.

Brumbaugh, W. G., Krabbenhoft, D. P., Helsel, D. R., Wiener, J. G. and Echols, K. R.: 2001, A National Pilot Study of Mercury Contamination of Aquatic Ecosystems Along Multiple Gradients: Bioaccumulation in Fish, U.S. Geological Survey, Columbia, MO, Biological Science Report USGS/BRD/BSR-2001-0009, 25 pp.

Bunton, T. E., Baksi, S. M., Gelrge, S. G. and Frazier, J. M.: 1987, 'Abnormal hepatic copper storage in a teleost fish (Morone americana)', Vet. Pathol. 24, 515-524.

Colborn, T.: 1991, 'Epidemiology of Great Lakes bald eagles', J. Toxicol. Environ. Health 33, 395453.

Crawford, J. K. and Luoma, S. N.: 1993, Guidelines for Studies of Contaminants in Biological Tissues for the National Water-Quality Assessment Program, U.S. Geological Survey, Reston, VA, OpenFile Report Nr. 92-494, 69 p.

Eisler, R.: 1985, Cadmium Hazards to Fish, Wildlife, and Invertebrates: A Synoptic Review, U.S. Fish and Wildlife Service, Washington, DC, Biol. Rep. 85(1.2).

Eisler, R.: 1994, 'A Review of Arsenic Hazards to Plants and Animals with Emphasis on Fishery and Wildlife Resources', in J. O. Nriagu (ed.), Arsenic in the Environment, Part II: Human Health and Ecosystem Effects, Wiley, New York, pp. 185-260.

Farag, A. M., Boese, C. J., Woodward, D. F. and Bergman, H. J.: 1994, 'Physiological changes and tissue metal accumulation in rainbow trout exposed to foodborne and waterborne metals', Environ. Toxicol. Chem. 13, 2021-2029.

Farag, A. M., Stansbury, M. A., Hogstrand, C., MacConnell, E. and Bergman, H. L.: 1995, 'The physiological impairment of free-swimming brown trout exposed to metals in the Clark Fork River, Montana', Can. J. Fish. Aquat. Sci. 52, 2038-2050.

Garbarino, J. R., Hayes, H. C., Roth, D. A., Antweiler, R. C., Brinton, T. I. and Taylor, H. E.: 1995, 'Heavy Metals in the Mississippi River', in R. H. Meade (ed.), Contaminants in the Mississippi River, 1987-1992, U.S. Geological Survey, Denver, CO, Circular 133, pp. 53-72.

Goldstein, R. M., Brigham, M. E. and Stauffer, J. C.: 1996, 'Comparison of mercury concentrations in liver, muscle, whole bodies, and composites of fish from the Red River of the North', Can. J. Fish. Aquat. Sci. 53, 244-252.

Goldstein, R. M. and DeWeese, L. R.: 1999, 'Comparison of trace element concentrations in tissue of common carp and implications for monitoring', J. Am. Water Resour. Assoc. 35, 1133-1140.

Gooch, J. W. and Matsamura, F.: 1987, 'Toxicity of chlorinated bornane (toxaphene) residues isolated from Great Lakes lake trout (Salvelinus namaycush)', Arch. Environ. Contam. Toxicol. 16, 349355.

Goolsby, D.: 1996, NASQAN II, Redesign Plan for the National Stream Quantity Accounting Network, U.S. Geological Survey, Water Resources Division, Reston, Virginia, pp. 30-60. 
Gundersen, D. T., Miller, R., Mischler, A., Elpers, K., Mims, S. D., Millar, J. G. and Blazer, V.: 2000, 'Biomarker response and health of polychlorinated biphenyl and chlordane-contaminated paddlefish from the Ohio River Basin, U.S.A.', Environ. Toxicol. Chem. 19, 2275-2285.

Harrison, S. E. and Klaverkamp, J. F.: 1990, 'Metal contamination in liver and muscle of northern pike (Esox lucius) and white sucker (Catostomus commersoni) and in sediments from lakes near the smelter at Flin Flon, Manitoba', Environ. Toxicol. Chem. 9, 941-956.

Heiny, J. S. and Tate, C. M.: 1997, 'Concentration, distribution, and comparison of selected trace elements in bed sediment and fish tissue in the South Platte River Basin, U.S.A., 1992-1993', Arch. Environ. Contam. Toxicol. 32, 246-259.

Henny, C. L., Blus, L. J., Hoffman, D. J. and Grove, R. A.: 1994, 'Lead in hawks, falcons and owls downstream from a mining site on the Coeur d'Alene River, Idaho', Environ. Monit. Assess. 29, 267-288.

Hirsch, R. M., Alley, M. and Wilber, W. G.: 1988, Concepts for a National Water-Quality Assessment Program, U.S. Geological Survey, Reston, VA, Circular 1021, 42 p.

Horowitz, A. J., Elrick, K. A. and Smith, J. J.: 2001, 'Annual suspended sediment and trace element fluxes in the Mississippi, Columbia, Colorado, and Rio Grande drainage basins', Hydrol. Process. 15, 1169-1207.

Hunter, R. G., Carroll, J. H. and Butler, J. S.: 1981, 'The relationship of trophic level to arsenic burden in fish of a southern Great Plains lake', J. Freshw. Ecol. 1, 121-127.

Jarvinen, A. W. and Ankley, G. T.: 1999, Linkage of Effects to Tissue Residues: Development of a Comprehensive Database for Aquatic Organisms Exposed to Inorganic and Organic Chemicals, SETAC Press, Pensacola, FL, 358 p.

Jearld Jr., A.: 1983, 'Age Determination', in L. A. Nielsen and D. L. Johnson (eds), Fisheries Techniques, American Fisheries Society, Bethesda, MD, pp. 301-324.

Kalkhoff, S. J., Savoca, M. E., Tobias, J. L., Sadorf, E. M. and Birkenholtz, T. L.: 1994, National Water-Quality Assessment Program - Eastern Iowa Basins, U.S. Geological Survey, Iowa City, IA, Fact Sheet 94-031, 2 p.

Law, R. J.: 1996, 'Metals in Marine Mammals', in W. N. Beyer, G. H. Heinz and A. W. RedmonNorwood (eds), Environmental Contaminants in Wildlife: Interpreting Tissue Concentrations, Lewis Publishers, Boca Raton, FL, pp. 357-376.

Lemly, A. D.: 1996, 'Selenium in Aquatic Organisms', in W. N. Beyer, G. H. Heinz and A. W. Redmon-Norwood (eds), Environmental Contaminants in Wildlife: Interpreting Tissue Concentrations, Lewis Publishers, Boca Raton, FL, pp. 427-445.

Lowe, T. P., May, T. W., Brumbaugh, W. G. and Kane, D. A.: 1985, 'National Contaminant Biomonitoring Program - Concentrations of seven elements in freshwater fish, 1978-1981', Arch. Environ. Contam. Toxicol. 14, 363-388.

Maeda, S.: 1994, 'Biotransformation of Arsenic in the Freshwater Environment', in J. O. Nriagu (ed.), Arsenic in the Environment, Part I: Cycling and Characterization, Wiley, New York, pp. $155-187$.

Mallory, M. J.: 1994, National Water-Quality Assessment Program - The Mississippi Embayment, U.S. Geological Survey, Water Resources Division, Jackson, MS, Fact Sheet 94-047, 2 p.

May, T. W. and McKinney, G. L.: 1981, 'Cadmium, mercury, arsenic, and selenium concentrations in freshwater fish, 1976-1977, National Pesticide Monitoring Program', Pestic. Monit. J. 15, 14-38.

Meade, R. H.: 1995, Contaminants in the Mississippi River, 1987-1992, U.S. Geological Survey, Denver, CO, Circular 1133, 140 p.

Messer, J. J., Linthurst, R. A. and Overton, W. S.: 1991, 'An EPA program for monitoring ecological status and trends', Environ. Monit. Assess. 17, 67-78.

Pita, F. W. and Hyne, N. J.: 1975, 'The depositional environment of zinc, lead, and cadmium in reservoir sediments', Water Res. 9, 701-706. 
Rostad, C. E.: 1997, 'From the 1988 drought to the 1993 flood: Transport of halogenated organic compounds with the Mississippi River suspended sediment at Thebes, Illinois', Environ. Sci. Technol. 31, 1308-1312.

Schmitt, C. J.: 1999, 'Environmental Contaminants', in M. J. Mac, P. A. Opler, C. E. Puckett Haecker and P. D. Doran (eds), Status and Trends of the Nation's Biological Resources, Vol. 1, U.S. Department of the Interior, U.S. Geological Survey, Reston, VA, pp. 131-166.

Schmitt, C. J. (ed.): 2002a, Biomonitoring of Environmental Status and Trends (BEST) program: Environmental Contaminants and their Effects on Fish in the Mississippi River Basin, U.S. Geological Survey, Biological Resources Division, Biological Science Report USGS/BRD/BSR 2002-0004, Columbia, MO, 217 p.

Schmitt, C. J.: 2002b, 'Organochlorine chemical residues in fish from the Mississippi River basin, 1995', Arch. Environ. Contam. Toxicol. 43, 81-97.

Schmitt, C. J., Blazer, V. S., Dethloff, G., Tillitt, D. E., Gross, T. S., DeWeese, L. R., Smith, S. B., Goede, R. W., Bartish, T. A. and Kubiak, T. J.: 1999a, Biomonitoring of Environmental Status and Trends (BEST) Program: Field Procedures for Assessing the Exposure of Fish to Environmental Contaminants, U.S. Geological Survey, Biological Resources Division, Columbia, MO, Information and Technology Report USGS/BRD-1999-0007, 68 pp.

Schmitt, C. J. and Brumbaugh, W. G.: 1990, 'National Contaminant Biomonitoring Program: Concentrations of arsenic, cadmium, copper, lead, mercury, selenium, and zinc in freshwater fishes of the United States, 1976-1984', Arch. Environ. Contam. Toxicol. 19, 731-747.

Schmitt, C. J. and Bunck, C. M.: 1995, 'Persistent Environmental Contaminants in Fish and Wildlife', in E. T. LaRoe, G. S. Farris, C. E. Puckett, P. D. Doran and M. J. Mac (eds), Our Living Resources: A Report to the Nation on the Distribution, Abundance, and Health of U.S. Plants, Animals, and Ecosystems, National Biological Service, Washington, DC, pp. 413-416.

Schmitt, C. J., Caldwell, C. A., Olsen, B., Serdar, D. and Coffey, M.: 2002, 'Inhibition of erythryocyte $\delta$-aminolevulinic acid dehydratase (ALAD) activity in fish from waters affected by lead smelters', Environ. Monit. Assess. 77, 99-119.

Schmitt, C. J. and Dethloff, G. M.: 2000, Biomonitoring of Environmental Status and Trends (BEST) Program: Selected Methods for Monitoring Chemical Contaminants in Aquatic Ecosystems, U.S. Geological Survey, Biological Resources Division, Columbia, Missouri, Information and Technology Report USGS/BRD/ITR - 2000-0005, 81 p.

Schmitt, C. J., Dwyer, F. J. and Finger, S. E.: 1984, 'Bioavailability of $\mathrm{Pb}$ and $\mathrm{Zn}$ from mine tailings as indicated by erythrocyte $\delta$-aminolevulinic acid dehydratase (ALA-D) activity in suckers (Pisces: Catostomidae), Can. J. Fish. Aquat. Sci. 41, 1030-1040.

Schmitt, C. J., Wildhaber, M. L., Hunn, J. B., Nash, T., Tieger, M. N. and Steadman, B. L.: 1993, 'Biomonitoring of lead-contaminated Missouri streams with an assay for erythrocyte $\delta$ aminolevulinic acid dehydratase activity in fish blood', Arch. Environ. Contam. Toxicol. 25, 464-475.

Schmitt, C. J., Zajicek, J. L., May, T. W., and Cowman, D. F.: 1999b, 'Organochlorine residues and elemental contaminants in U.S. freshwater fish, 1976-1986: National Contaminant Biomonitoring Program', Rev. Environ. Contam. Toxicol. 162, 43-104.

Settle, D. M. and Patterson, C. C.: 1980, 'Lead in albacore: Guide to lead pollution in Americans', Science 207, 1167-1176.

Stansley, W. and Roscoe, D. E.: 1999, 'Environmental toxicology-chlordane poisoning of birds in New Jersey, U.S.A.', Environ. Toxicol. Chem. 18, 2095-2099.

Taylor, L. N., McGeer, J. C., Wood, C. M. and McDonald, D. G.: 2000, 'Physiological effects of chronic copper exposure to rainbow trout (Oncorhynchus mykiss) in hard and soft water: Evaluation of chronic indicators', Environ. Toxicol. Chem. 19, 2298-2308.

Tillitt, D. E., Ankley, G. T., Giesy, J. P., Ludwig, J. P., Kurita-Matsuba, H., Weseloh, D. H., Ross, P. S., Bishop, C. A., Sileo, L., Stromborg, K. L., Larson, J. and Kubiak, T. J.: 1992, 'Polychlor- 
inated biphenyl residues and egg mortality in double-crested cormorants from the Great Lakes', Environ. Toxicol. Chem. 11, 1281-1288.

Trefry, J. H. S., Metz, S., Trocine, R. P. and Nelsen, T. A.: 1985, 'A decline in lead transport by the Mississippi River', Science 230, 439-441.

U.S. Council on Environmental Quality: 1997, Sustainable Development in the U.S.: An Experimental Set of Indicators - Interim Report, CEQ, Interagency Sustainable Development Indicators Working Group, Washington, D.C.

U.S. Environmental Protection Agency (U.S. EPA): 1984, Ambient Water Quality Criteria for Arsenic, EPA 440/5-84-037, Washington DC.

U.S. EPA: 2000, Guidance for Data Quality Assessment - Practical Methods for Data Analysis, Office of Environmental Information, Washington, D.C., Report EPA/600/R-96/084, EPA QA/G9, QA00 update.

Wageman, R., Snow, N. B., Rosenberg, D. M. and Lutz, A.: 1978, 'Arsenic in sediments, water and aquatic biota from lakes in the vicinity of Yellowknife, Northwest Territories, Canada', Arch. Environ. Contam. Toxicol. 7, 169-191.

Wiener, J. G., Krabbenhoft, D. P., Heinz, G. H. and Scheuhammer, A. M.: 2002, 'Ecotoxicology of Mercury', in D. J. Hoffman, B. A. Rattner, G. A. Burton Jr. and J. Carins Jr. (eds), Handbook of Ecotoxicology, 2nd ed., CRC Press, Boca Raton, FL, pp. 407-461.

Wildhaber, M. L., Allert, A. L., Schmitt, C. J., Tabor, V. M., Mulhern, D., Powell, K. L. and Sowa, S. P.: 2000, 'Natural and anthropogenic influences on the distribution of the threatened Neosho madtom in a Midwestern warmwater stream', Trans. Am. Fish. Soc. 129, 243-261.

Woodward, D. F., Goldstein, J. N. and Farag, A. M.: 1997, 'Cutthroat trout avoidance of metals and conditions characteristic of a mining waste site: Coer d'Alene River, Idaho', Trans. Am. Fish. Soc. 126, 699-706.

Yeardley Jr., R. B., Lazorchak, J. M. and Paulsen, S. G.: 1998, 'Elemental fish tissue contamination in northeastern U.S. lakes: Evaluation of an approach to regional assessment', Environ. Toxicol. Chem. 17, 1875-1884. 